\title{
Probable late Messinian tsunamiites near Monte Dei Corvi, Italy, and the Nijar Basin, Spain: expected architecture of offshore tsunami deposits
}

\author{
Jan Smit • Cor Laffra $\cdot$ Karlien Meulenaars $\cdot$ Alessandro Montanari
}

Received: 1 February 2010/Accepted: 15 August 2011/Published online: 22 September 2011

(C) The Author(s) 2011. This article is published with open access at Springerlink.com

\begin{abstract}
Three distinct, 30- to 80-cm-thick, graded, multilayered, coarse-grained sandstone layers, intercalated in the late Messinian mudstones of the Colombacci formation in Lago Mare facies of the Trave section are interpreted as tsunamiites (Ts1-Ts3). Each of these layers is sheet-like and could be followed along strike over several tens of meters. The lower two layers (Ts1-Ts2) occur in the lower part of the Colombacci formation and the third (Ts3) just below a conspicuous white "colombacci" limestone near the top of the formation. The three sandstone layers represent unique sedimentary events within the 120-m-thick San Donato-Colombacci mudstones, which contain many thin, finegrained, possibly storm-related turbidites. Each of the three clastic layers is overall graded and strongly cross-bedded. A single layer consists of a stack of several graded sublayers that are eroded into the underlying mudstones and into each other. Absence of hummocky cross-stratification (HCS) indicates that the layers are not produced during a large, catastrophic storm event. Current ripples such as dm-sized trough cross-beds suggest strong, prolonged, unidirectional currents, capable of carrying coarse conglomeratic sands. Climbing ripples in middle-fine sand units indicate a high suspension load settling under waning current strength. Each of the Ts1-Ts3 beds satisfies a combination of criteria, described in this paper, that allow interpretation as a tsunamiite in an offshore environment. Tsunamiite Ts 2 is underlain by a $15-\mathrm{cm}$-thick meshwork of synsedimentary fissures, filled with coarse sand. Ground movements induced by strong earthquakes probably caused these crevasses. The uniqueness of each layer, the erosion of the base of each of the sublayers into underlying mudstones and previously deposited sublayer and the consistent stacking of graded sandstone beds within each of the three layers, underlain by earthquakeproduced fissures, strongly point to deposition by traction currents produced by the surges of a large tsunami event, triggered by a large vertical fault movements. Vertical fault displacements most likely occurred along the thrust faults like the Sibilline thrust at the SW of the Laga foreland basin, which were active at late Messinian times. A series of
\end{abstract}

J. Smit $(\bowtie) \cdot$ C. Laffra $\cdot$ K. Meulenaars

$\mathrm{Vu}$ University Amsterdam, de Boelelaan 1085, 1018HV Amsterdam, The Netherlands e-mail: jan.smit@falw.vu.nl 
cyclic graded turbidites, underlain by seismically induced sand-filled fissures in the Late Messinian Feos formation in SE Spain, are interpreted as tsunamiites produced by a tsunami or seiche.

Keywords Paleo-tsunami deposits $\cdot$ Tsunamiite $\cdot$ Lago Mare $\cdot$ Messinian

\section{Introduction}

The recognition and detection of tsunami deposits in the geological record could be an important tool for the evaluation of the frequency and magnitude of past tsunami activity. Tsunamis are invariably triggered by an energetic (convulsive) event. Often-cited 'triggers' include subduction-related earthquakes (Sumatra 2004, Japan 2011), landslides (Dawson and Steward 2007), submarine landslides (Storegga) (Dawson et al. 1988), volcanic eruptions of Santorini, (Cita 2008), Krakatoa (Van den Berg et al. 2003) and large extraterrestrial body impacts in and near ocean basins (Bourgeois et al. 1988; Smit et al. 1996). Sedimentary deposits directly or indirectly caused by tsunamis are known as tsunamites or tsunamiites (Shiki and Yamazaki 2008). We prefer here to use the latter term.

Tsunami deposits are best known from modern onshore, intra-tidal to supra-tidal areas. Most tsunami research is centered in these environments, and these are relevant for the evaluation of tsunami activity in recent and historical context. However, such areas are prone to erosion (Dawson and Steward 2007; Bourgeois et al. 1988). Specifically, those regions near subduction-related earthquakes, where most supra-tidal tsunami deposits can be expected, are on uplifting rather than subsiding crust, facilitating erosion. Such supra-tidal areas are poorly suited for the research of tsunami activity in the more distant geological record.

The deeper (below base level) offshore marine environment offers a much better potential for the preservation of tsunamiites in the geological record. Deep-water (up to $4,000 \mathrm{~m}$ ) tsunamiites are thus far known to result from the Chicxulub impact in the western Atlantic basin (Norris et al. 2000) and the catastrophic Holocene eruption of the Santorini (Thera) volcano (Shiki and Cita 2008; Cita 2008). The latter deposits are known as 'homogenites'. Cita (2008) distinguished a type 'A' homogenite in small basins on the Mediterranean ridge and a type ' $\mathrm{B}$ ' homogenite that is basically a megaturbidite. Homogenite ' $A$ ' is a pelagic turbidite consisting of oozes remobilized by the shuttle movements of the 'shallow-water tsunami wave' on the seafloor (Sugawara et al. 2008) and tend to accumulate as pelagic sediment, muddy gravity flows into flat-floored depressions close to the remobilized areas (Cita 2008; Shiki and Cita 2008). Such 'shallow-water waves' are characterized by very long wavelengths - about $>20$ times longer-compared to the depth of the ocean and a very small $(<1-2 \mathrm{~m})$ amplitude. The horizontal water movements of such long waves are the same throughout the water column (Sugawara et al. 2008) and are normally not strong enough to remobilize sea floor oozes. However, the 'Bernoulli effect' over the crest of the Mediterranean ridge may have caused the necessary increase in current traction on the seafloor to remobilize the oozes in this specific case. The type ' $\mathrm{B}$ ' homogenite is probably triggered by the backflow(s) of the tsunami (Cita 2008) from shallow waters in the Sirte Gulf in view of the abundance of shallow-water fossils. The sediment-laden high-density backflow developed downslope into something akin to a megaturbidite deposit (Mulder et al. 2009). Yet, characteristic sedimentary features that unequivocally (without evidence tying the deposits to the Santorini eruption) define it as a tsunamiite are not expected from such gravity flow deposits, beyond a few possible grain size 'jumps'. 
The offshore environment from just below storm wave-base level of 10-200 m water depths is probably the best environment to investigate and demonstrate the occurrence of tsunami activity in the geological record. Recent observations indicate that the bulk of redeposited clastic sediment after a tsunami event is in offshore rather than onshore direction (MacInnes et al. 2009) (Fig. 1). Yet, surprisingly few investigations have taken place in the offshore region. As Dawson and Stewart (2008) state, these marine environments are the "forgotten tsunami sedimentation process". The reason behind the paucity of investigations can be manifold, but often such areas are within territorial waters, with restricted access for research vessels. Additionally, unequivocal offshore tsunamiites have not been recognized yet in the geological record because of a lack of good descriptions and diagnostic criteria for such deposits.

Most of the known suspected offshore tsunamite deposits in the geological record are related to large impact events. Coarse, graded, sandstone deposit are associated with the Chicxulub crater at the K/T boundary around the Gulf of Mexico (Bourgeois et al. 1988; Smit et al. 1996), the Manson crater in the late Cretaceous, the Lockne crater in the
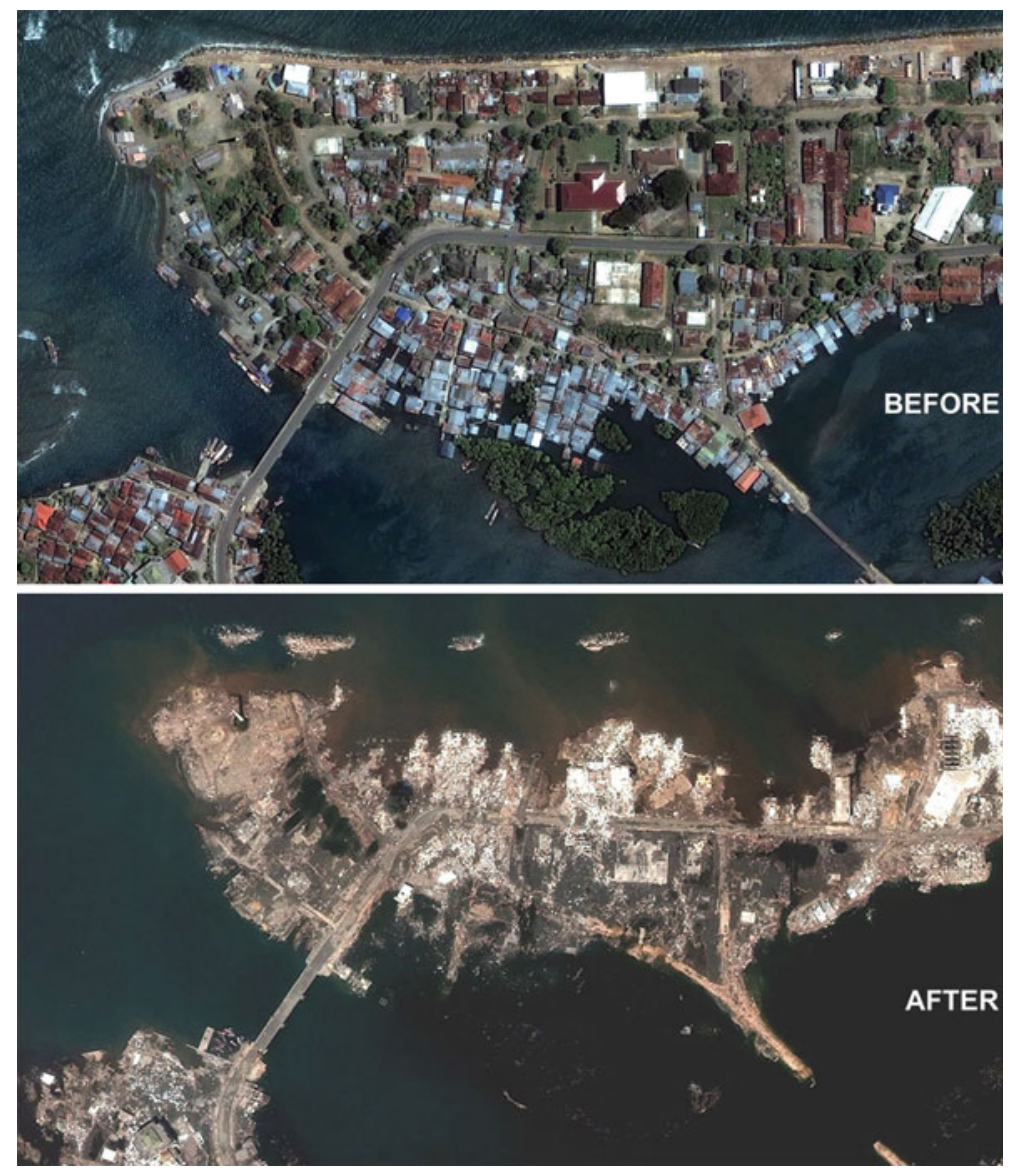

Fig. 1 The coast near Banda Aceh, before (upper) and after the 2004 tsunami. The majority of the eroded unconsolidated sediments were washed offshore, rather than deposited onshore, by the backflow of the tsunami surges 
mid-Ordovician (Izett et al. 1993; Sturkell et al. 2000), and the early Proterozoic tsunamiites with impact spherules in the Hamersley Basin in Australia (Hassler et al. 2000).

Where to look for possible and recognizable tsunamiites? The frequency of large earthquake-triggered tsunamis is unquestionably high at the continental shelf near subduction zones. Passive margins are usually farther away from the source. The effective depth, i.e., the depth where tsunami deposits can be recognized as such, of tsunamiinfluenced sediment will diminish with distance and may be well in reach of the wave base of large storms and be often obliterated by the reworking effects of the storm waves, changing its texture into those of tempestites. If a typical tsunamiite, standing out from a tempestite, is discovered on distal continental margins, it is expected that these in majority may be triggered by large-body impact. It is questionable whether tsunamiites triggered by large subduction-related earthquakes will be found — or may be extremely rare-in passive margin settings, because the passive margin is often far away from the source, except in smaller basins like the Mediterranean. Subduction-related tsunami waves may have lost so much energy that its effects can be difficult to distinguish from those of tidal currents.

In our search for additional candidate tsunamiites in the geological record, we have discovered coarse-grained, multiple-layered, graded sandstone layers in the Messinian Colombacci formation exposed on the Adriatic coast near Monte Dei Corvi, Italy, and cyclic sandstone layers in Spain (Fig. 2). The three Monte dei Corvi beds (Ts1-Ts3) occur on the eastern edge of the Apennine fore-deep basin (Fig. 3). These three beds share many characteristics in texture and structure with each other. The beds are intercalated in offshore mudstones that contain numerous thin fine-grained turbidites, which differ from the three beds, because they represent a thin single-graded layer. In this paper, we describe the sedimentologic architecture of these three beds. Cyclic turbiditic sandstone beds associated with seismic shaking in coeval beds in Lago Mare facies of the Feos formation in the Nijar Basin, Spain, are compared with the tsunamiites Ts1-Ts3 and reinterpreted as tsunamiites.

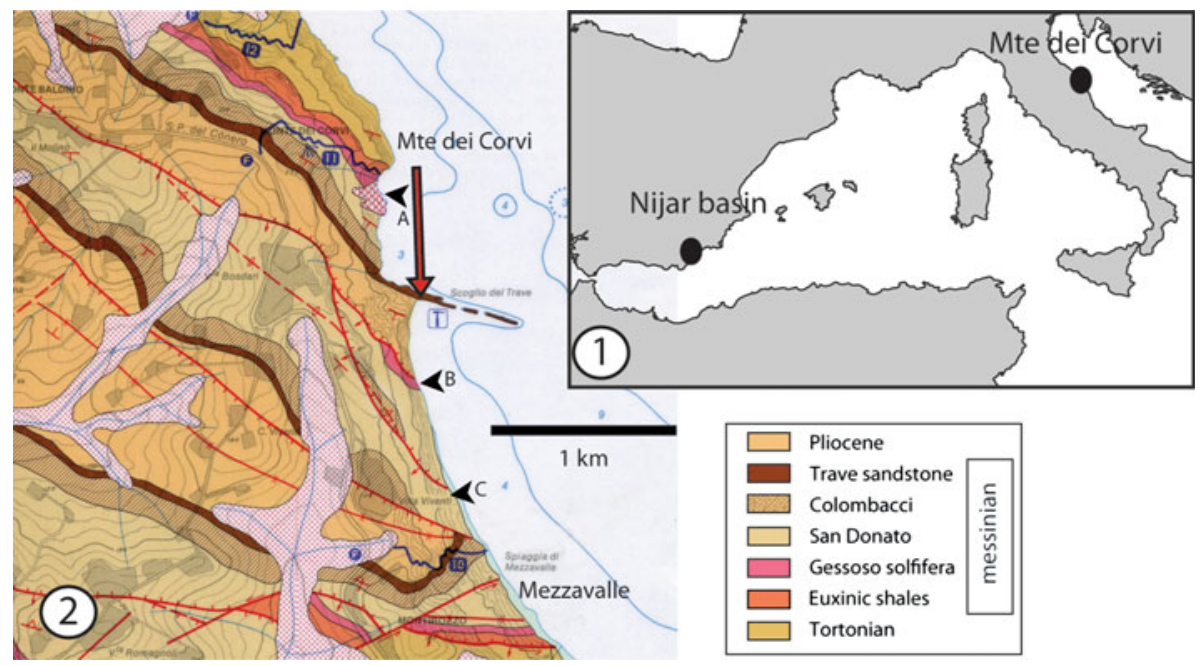

Fig. 21 Location of the study areas. 2 Geological map of the Monte dei Corvi, with the measured section $(A)$ and the two sections $(B, C)$ on Mezzavalle beach where the Gessoso-solfifera fm is exposed 


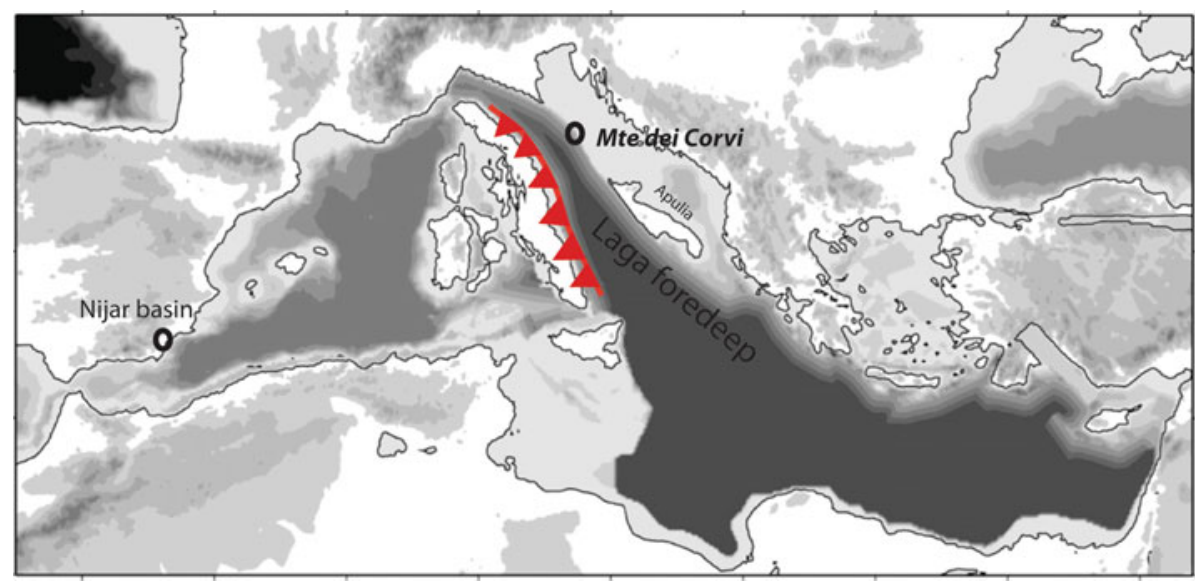

Fig. 3 Paleogeography of the Mediterranean in the Messinian (after Govers et al. 2009). The foredeep basin originated by thrust folding along the Sibillini thrust front. The Mte dei Corvi section is in the Apulian side of the foredeep and well suited to receive tsunamis triggered by strong vertical movements along the Sibillini thrust fault

\section{Geological setting}

Between Monte Dei Corvi and Scoglio del Trave, a complete Messinian succession-the Trave section-is exposed along the Adriatic coast (Figs. 4, 5, 6). The Messinian section is about $243 \mathrm{~m}$ thick and consists of a series of lithological units that reflect the local history of the onset and termination of the Messinian Salinity Crisis (MSC) (Roveri et al. 2005; Roveri et al. 2001). From bottom to top, the succession is divided into five units: (Fig. 5).

The upper part of the Schlier fm, 'Formazione di letto', or euxinic Shale unit (Montanari et al. 1997), consists of $\sim 15$-m-thick, fully marine pelagic sediments displaying rhythmic alternations of dm-thick sapropels and bioturbated marly limestones, interpreted as orbitally forced, mainly precession, cycles (Hilgen et al. 2007a; Husing et al. 2007). The euxinic shales are the pre-evaporite prelude to the MSC, and the increase in thickness of the black, organic C-rich sapropel interbeds probably indicates the increasing closure of the Mediterranean Basin.

The overlying interval is the 'Lower Evaporites' or Gessoso-Solfifera fm. The sapropels of the euxinic shales increase in thickness and organic carbon content toward the $\sim 30-\mathrm{m}$ thick evaporitic Gessoso-solfifera fm, which consists of 16/17, 100- to 180-cm-thick couplets of laminated euxinic shales and laminated primary gypsum layers. Both layers, but mostly the gypsum beds, contain syn- to post-sedimentary, ingrown, tree-like, selenite gypsum crystal aggregates, up to $80 \mathrm{~cm}$ in size. The interval of interbedded laminated black shales and gypsum layers is almost identical to those of the lower evaporite of the Yesares fm of the Sorbas Basin (Krijgsman et al. 2002). Also, these cycles are probably orbitally forced [precession (Hilgen et al. 2007b)]. The contact between the formations is unfortunately not exposed in the Trave section. Twelve of the (precession) gypsum cycles of the presumably 16 (Manzi et al. 2007) could be counted in the adjacent sections $1.3 \mathrm{~km}$ toward the SE on the Mezzavalle beach. Both the laminated euxinic shale and the laminated gypsum layers contain many whole specimens of the small, thick-boned, extreme 


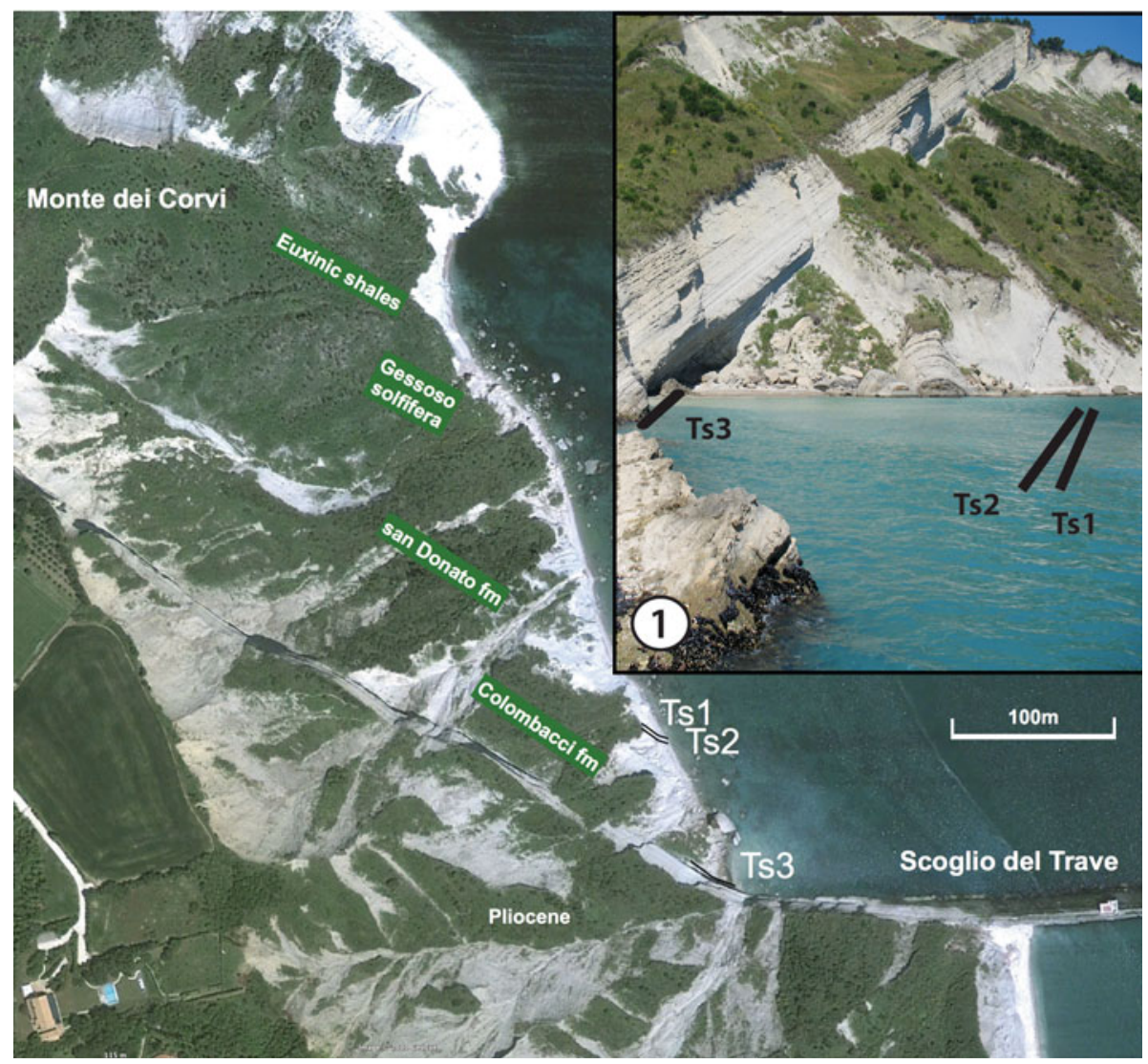

Fig. 4 Outcrop overview with the location of the tsunamiites Ts1-Ts3 (Google Maps). 1 Image taken from the Scoglio del Trave, showing the position of tsunamiites Ts1-Ts3

environment-tolerant (high salinity) fish Aphanius crassicaudus, (Reichenbacher and Kowalke 2009). The next interval consists of the san Donato and Colombacci formations, described below. The highest unit of the Trave section is the Trave fm, a 15-m-thick, medium-bedded (20-25 cm), shore-face, and bioturbated medium-to-fine-grained sandstone. The Trave fm marks the final shallowing of the Messinian succession, although (Roveri et al. 2005) suggest a lowermost Pliocene age for the Trave sandstone. The Trave is resistant to erosion and forms a hard ledge - a 'reef-like' feature, the "Scoglio del Trave" in the sea (Fig. 4). The Trave contains in situ double-valved brackish water Limnocardium and sedimentary structures including hummocky cross-stratification (HCS) in less-bioturbated levels, in particular near the top. The Trave displays regular rhythmic, cyclic bedding, marked by thin, slightly softer, finer-grained interbeds. The cycles indicate regular changes in storm and/or bioturbation intensity, probably related to cyclic climatic changes. The $\sim 75$ rhythmic beds are deposited in less than $80 \mathrm{Ky}$ (Roveri et al. 2005), which suggest cyclicity on a millennial scale (J.S. unpublished data). These are in the range of the 'Bond cycles' (Bond et al. 1997). A bored hardground at the top forms the transgressive surface of the fully marine lower Pliocene. 


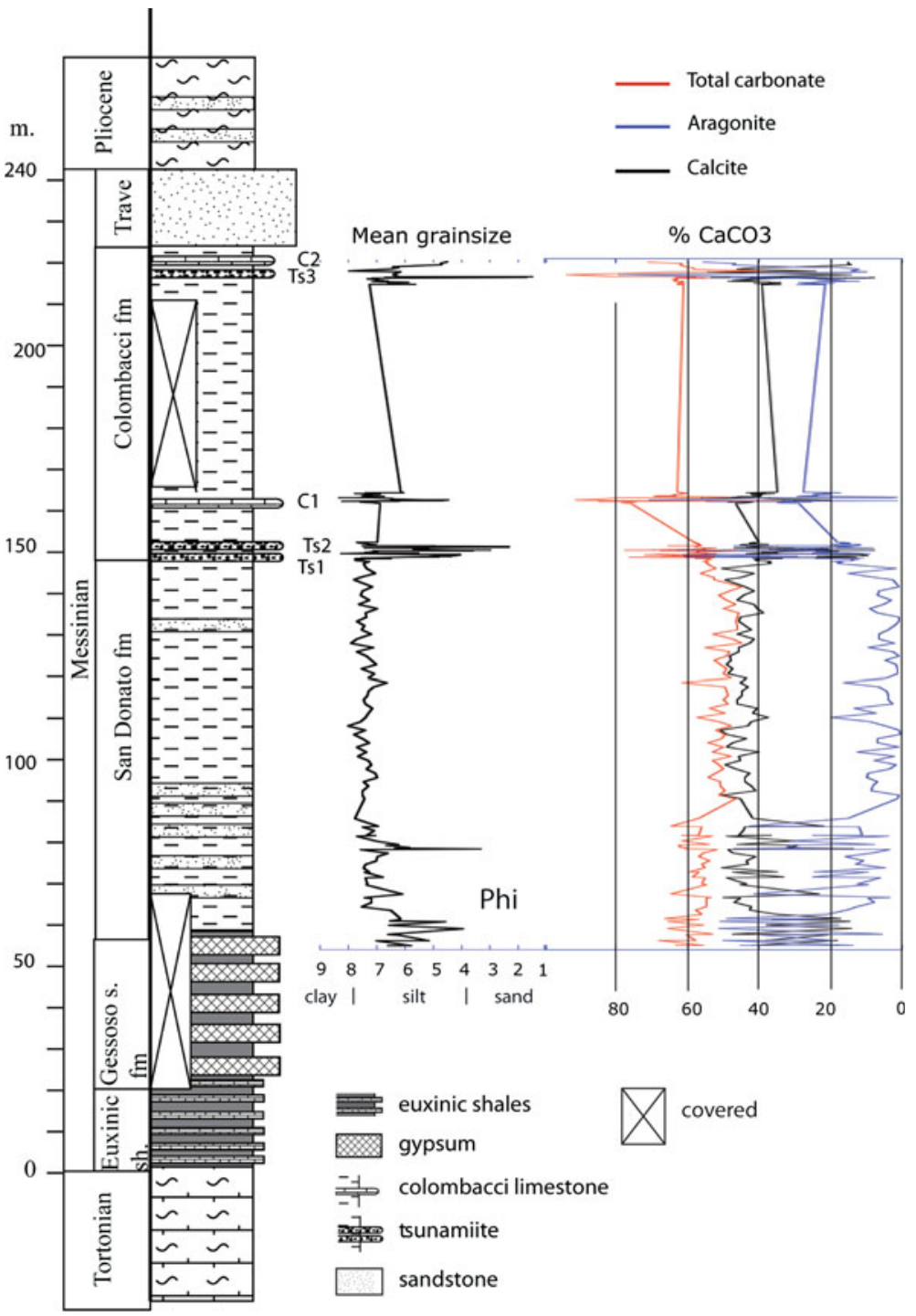

Fig. 5 Stratigraphic column, grain size, and carbonate TGA analyses of the measured Trave section. Ts1, Ts2, and Ts3 are the tsunamiites intercalated in the Colombacci fm. C1, C2; nannofossil-rich 'colombacci' layers. The modal grain size shows a slight grain size decrease from San Donato to Colombacci, but no trend toward Ts-1

\subsection{Upper Messinian San Donato and Colombacci formation}

The 92-m-thick San Donato formation (also named Tetto Fm) [P-ev1 of Roveri et al. (2005)] dominantly consist of monotonous silty mudstones with interbedded thin turbidites, in particular in the basal $50 \mathrm{~m}$. A 10-m-thick package in the middle of the formation is slumped. The San Donato fm represents the post-evaporitic Lago Mare phase and has been regarded as the clastic lateral equivalent of the 'Upper evaporites' (Roveri and Manzi 

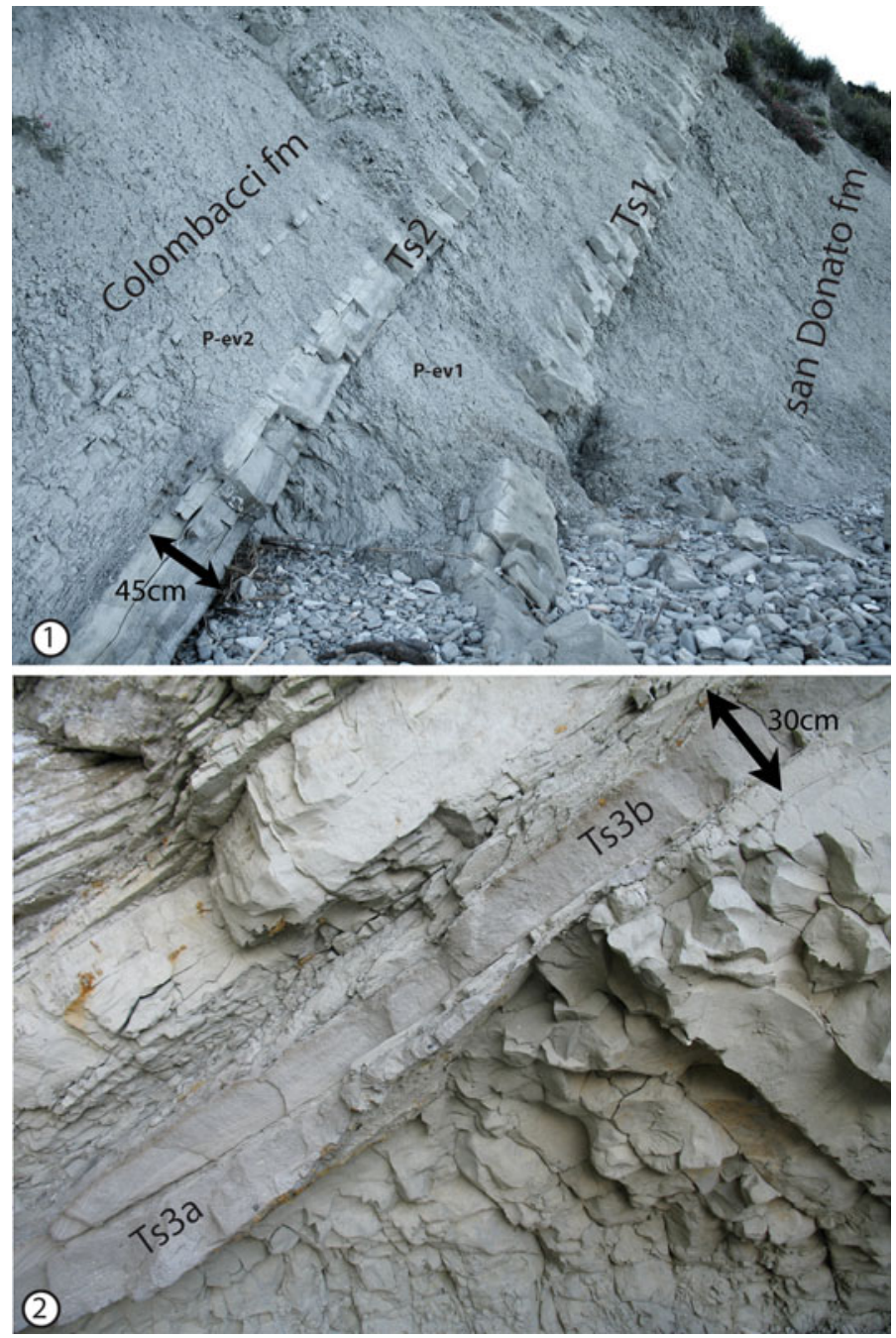

Fig. 61 Tsunamiites Ts1 and Ts2 intercalated in the mudstones of the post-evaporitic sequence P-ev1 (san Donato fm) and basal P-ev2 (Colombacci fm) (Roveri et al. 2005). 2 Tsunamiite Ts3, just below the Trave $\mathrm{fm}$. Ts $3 \mathrm{a}$ the lower and Ts $3 \mathrm{~b}$ the upper of the two graded subbeds

2006). Most authors assume the great Messinian dessication of the Mediterranean to occur between the lower and upper evaporites, at the base of the San Donato fm. The San Donato fm abruptly overlies the last gypsum cycle, possibly marking the short 90-ky hiatus caused by the sea level drop (Krijgsman et al. 2002). This contact is not exposed in the Trave section but is well visible on Mezzavalle beach (Fig. 2).

The 76-m-thick Colombacci formation [P-ev2 of Roveri et al. (2005)] is a continuation of the silty mudstone lithology of the san Donato fm., but it contains three 10- to $95-\mathrm{cm}$ thick complex, multiple-graded, gravel-sand layers, (Ts1-Ts3) at 157, 158, and $217 \mathrm{~m}$, (Fig. 5) described here. Roveri et al. (2005) place the boundary between (P-ev1/P-ev2) at the base of the lowest of the three sandstone layers. The Colombacci fm. in addition 
contains two about 1-m-thick, conspicuously white limestones ( $\mathrm{C} 1$ and $\mathrm{C} 2)$, the enigmatic "colombacci" layers, that contain marine nannofossils (Roveri et al. 2005; Popescu et al. 2007), possibly indicating initial flooding events, a short prelude to the opening of the Mediterranean to the Atlantic after the salinity crisis and before the major flooding at the base of the Pliocene (Popescu et al. 2007). The almost complete absence of microfossils in the san Donato/Colombacci mudstones precludes any reliable depth estimate of the Lago Mare Sea. However, the laminated, unsorted fine silty mudstones with intercalated thin turbidites, and the fine-grained pelagic nannofossil colombacci limestones indicate an offshore environment, below storm wave base.

\subsection{Messinian Lago Mare Feos formation, Nijar Basin, Spain}

In the eastern part of the small, enclosed Nijar Basin, SE Spain (Fortuin and Dabrio 2008; Fortuin and Krijgsman 2003), succession of Tortonian to Late Miocene Basin fill is described (Fig. 7). From bottom to top: the Turre, Yesares, and Feos formations. The fully marine Tortonian-Messinian Turre formation documents the transgressive sequence from coastal shallow calcarenites of the Azagador member to the fully marine pelagic Abad member marls that become progressively more euxinic upsection. The Yesares formation is comparable of the lower evaporites of the Gessoso-solfifera fm of the Trave section and contains cyclic alternations of laminated sapropels and gypsum layers.

The Feos formation is in the center of the basin $>100 \mathrm{~m}$ thick and consists of coarse continental clastic layers with paleosols, and white laminated Lago Mare lagoonal to brackish fine-grained mudstones with nannofossil and fine gypsum debris, comparable to the "colombacci" layers in the Trave section. The Feos fm. represents a series of cyclic alternations of continental clastic and lagoonal-lacustrine Lago Mare facies, interpreted as repeated periods of desiccation and reflooding of the Nijar embayment on orbital precession timescales (Krijgsman et al. 2002). Regarding the small size and isolation of the northern Nijar Basin, the embayment may have had a shallow base level. Near the hamlet of los Feos (Fortuin and Dabrio 2008) describe an outcrop in the locally developed Lago Mare facies (labeled LLM) of characteristic micritic, stark white, finely laminated, lacustrine-lagoonal chalks, interbedded with frequent thin-to-medium-bedded, well-sorted, graded sand beds, interpreted as turbidites. The varve-like laminations in LLM are preserved due to the total absence of any bioturbation. Many 'turbidites' occur in sets of two to three regularly spaced, thinning upward graded sandstone layers and are here reinterpreted as tsunami event beds.

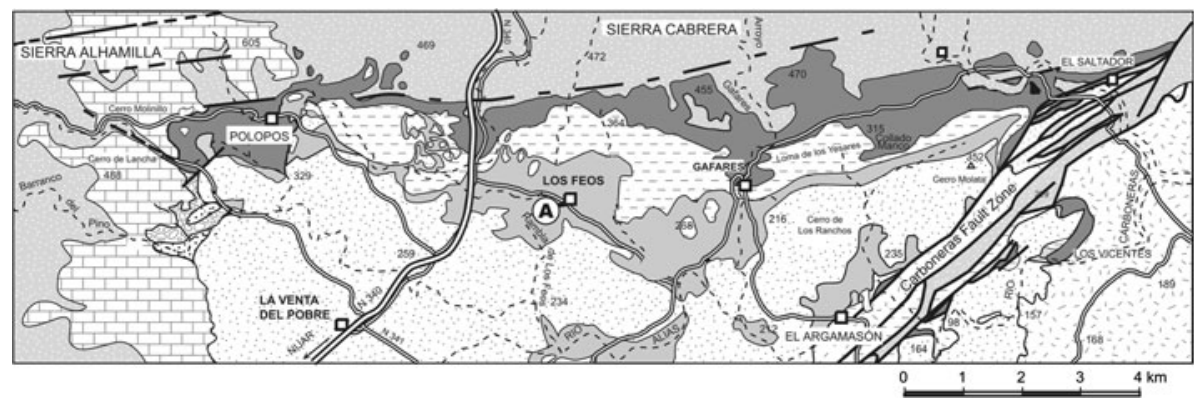

Fig. 7 Location of suspected seiche or tsunamiite beds near los Feos (A), Nijar Basin, South Spain. The boundary fault of the Sierra Cabrera is active in late Messinian times 
The Feos fm. is sharply overlain by the shallow marine calcarenites of the Pliocene Cuevas fm.

\section{Methods}

The lithology of the Trave section was logged in detail in the field (Fig. 5), and 250 samples were taken to perform a laser grain size analysis and thermogravimetric analysis (TGA) for carbonate content. The samples chosen for grain size analysis were mainly taken from the fine mudstones. Turbidites, except the coarse intervals, were avoided as much as possible. The interval between Ts 2 and Ts 3 could not be sampled because of landslides covering the outcrop. The mean grain size of the samples is coarse silt (phi scale 6) at the base of the section and constant fine silt of the upper part of the formation. The modal grain size gradually decreases in top of the san Donato, up till the first thick Ts1 Tsunamiite sandstone at the base of the Colombacci $\mathrm{fm}$. The coarse grain size at the basal $30 \mathrm{~m}$ reflects the influx of thin turbidites. The slight decrease in modal grain size above the slumps coincides with the decrease in number of turbidites.

Samples were dried and gently crushed, disaggregated, and dissolved in $\mathrm{HCl}$ and $\mathrm{H}_{2} \mathrm{O}_{2}$, to remove carbonate and sulfide authigenic phases. From the coarse sand and gravel-sized intervals of the sand layers, only the $<2 \mathrm{~mm}$ size was determined, because the laser grain size analyzer cannot handle larger grain sizes properly. The results of these layers therefore do not reflect the whole grain size distribution but nevertheless shows trends within these layers. Grain sizes were determined for a range of $0.15-2,000 \mu$. The 56 grain size classes, from which grain size histograms were made (Konert and VandenBerghe 1997), were contoured on grain size class percentile (Fig. 8).

An aliquot of the crushed samples was further finely ground for TGA to measure carbonate contents, organic $\mathrm{C}$ content and water.

The TGA method used includes a stepwise loss on ignition (LOI) method, developed at the VU university (Konert 2010 in preparation). At specific temperature intervals, from low to high temperatures, successively water $\left(<60-80^{\circ} \mathrm{C}\right)$, organic carbon $\left(90-105^{\circ} \mathrm{C}\right), \mathrm{CaCO}_{3} \mathrm{a}$

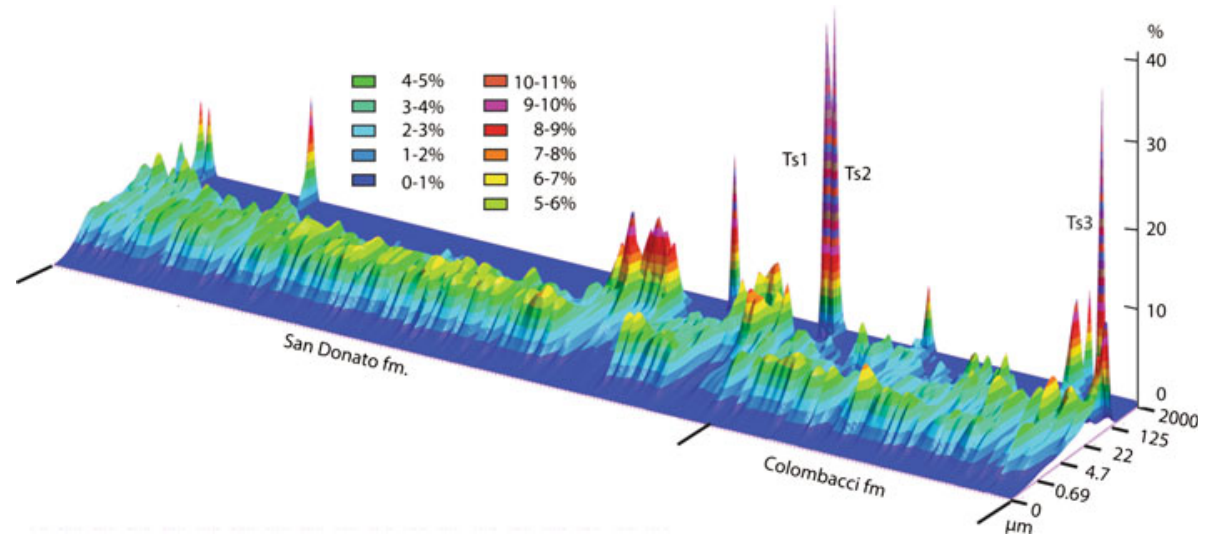

Fig. 8 Laser grain size analysis of the San Donato and Colombacci fm. plotted as a sequence of grain size histograms, contoured in stratigraphic order. The $\mathrm{X}$-axis has no scale, and samples are plotted in stratigraphic order from left to right 
$\left(155-190^{\circ}\right)$ (aragonite), and $\mathrm{CaCO}_{3} \mathrm{~b}\left(230-300^{\circ}\right)$ (calcite) are lost (vaporized) and quantified.

\section{Results}

\subsection{Ts1 (tsunamiite 1)}

This multiple-graded sandstone layer is constant in thickness $(80 \mathrm{~cm})$ over $>20 \mathrm{~m}$. Three hundred and fifty meters up the cliff at the same stratigraphic position, a similar, but thicker $>1.5 \mathrm{~m}$ coarse sandstone layer was visible but was not further studied. Ts1 layer is sheetlike, not channeled, although sublayers display shallow channeling. Ts1 consists of several (at least 4, possibly 6) graded sublayers, ranging in thickness from 5 to $10 \mathrm{~cm}$. Maximum grain size reaches up to fine granule size, $<0.8 \mathrm{~cm}$. Components include the following: well-rounded white quartz and subrounded dark chert pebbles, elongated clay pebbles. Micritic and bioclastic limestone grains form a major component, responsible for the high $\mathrm{CaCO}_{3}$ content (Fig. 9). Minor components are small white bivalve fragments. The basal sublayer does not erode visibly into the underlying mudstone, and sole marks were not observed. Each of the successive sublayers has eroded into the top of the underlying graded sublayer, removing (parts of) the finer-grained top of the previous sublayer. Medium-scale, high-angle tabular to trough cross-bedding was observed in four sublayers, with foresets prograding dominantly toward the SE. Some NW directions indicate a lateral trough infill direction. Well-developed climbing-ripple layers were observed at several levels, in intervals of fine-to-medium sand grain size. These climbing ripples are easily confused with HCS. The cross-bedding alternates with parallel laminated beds. The top unit is faintly laminated and grades into coarse silt in the top.

\subsection{Ts2 (tsunamiite 2)}

The base of Ts2 layer is $70 \mathrm{~cm}$ above the top of Ts1 and shares many characteristics with Ts1 but is coarser grained. The layer is also sheet-like but seems to pinch out slowly over $20 \mathrm{~m}$. It has not been observed at the top of the cliff and may be discontinuous. Ts 2 ranges in thickness from 50 to $60 \mathrm{~cm}$ and includes two conspicuous coarse $(<3 \mathrm{~cm}$ gravel at the base) graded trough cross-bedded units, each followed by two (three) finer-grained graded sand beds (Fig. 10). The beds are clearly channeled and erode into each other. The two coarse beds display medium-scale, high-angle trough cross-bedding, in particular the lowest bed. On the trough cross-bedding, a dominant E-to-W migration of the channel fill could be established. Foreset lamina are $4-6 \mathrm{~mm}$ thick and by itself normal to inversely graded (Fig. 11). Components include the following: rounded white quarz (vein-quartz) pebbles, angular black chert pebbles, and abundant micritic and bioclastic limestone fragments like in Ts1. In contrast to Ts1, the coarse-grained parts contain up to $50 \%$ white fragments of bivalves (limnocardium) and a few gastropods. Double-valved shells were not encountered; whole valves are mostly in current-stable concave-up position. The top two medium sand, graded beds are parallel laminated, and like Ts1, the topmost sand bed grades into a 5-cm-thick silt layer. The lowest of these sand layers contains abundant plant debris, indicating backwash from supra-tidal (lagoon) areas (Fig. 11).

The $5-10 \mathrm{~cm}$ top of the mudstones directly underlying Ts 2 contains a meshwork of conspicuous dark, 5- to 15-cm-long, fissure-like features that are filled with coarse sand (Fig. 10). The fissures often bifurcate and are in cross section elongated, and sometimes 

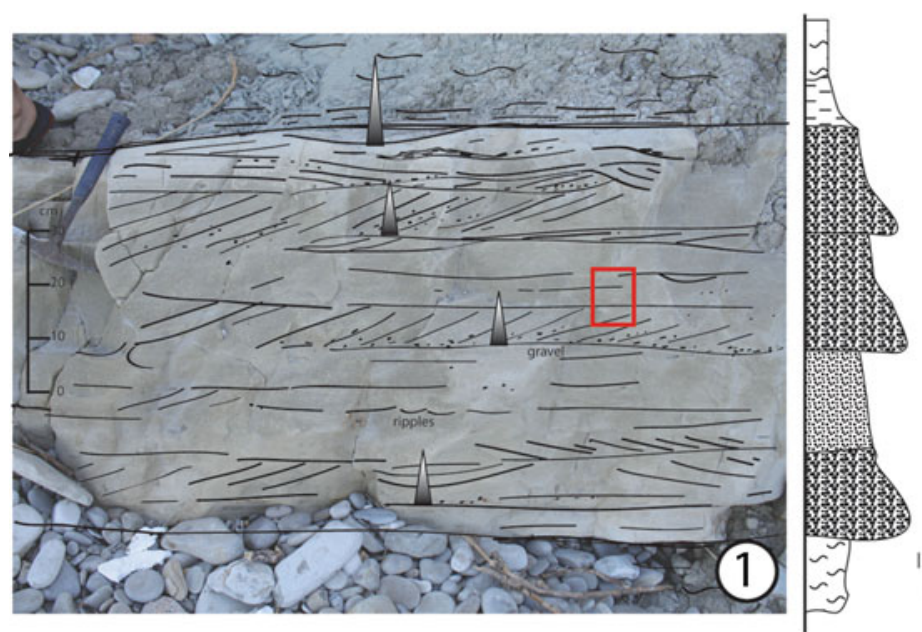

Ts1

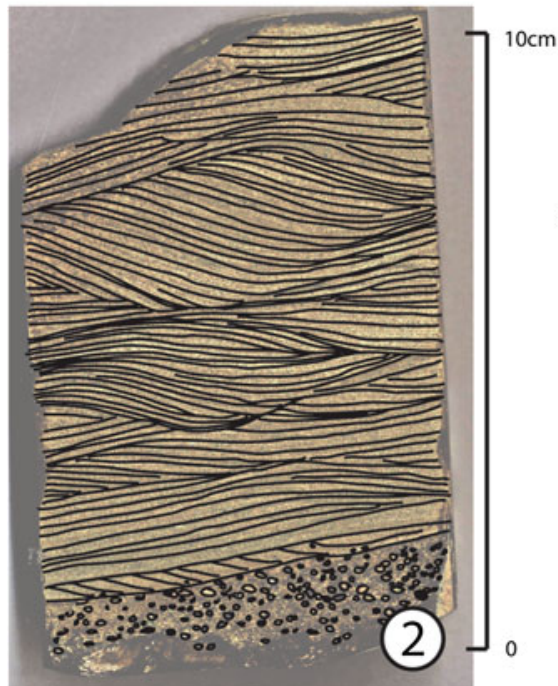

climbing ripples

Fig. 9 Lowest tsunamiite (Ts1). 1 Stack of three graded and cross-bedded sublayers, each eroding in the underlying mudstones or the underlying bed. The fourth graded unit is the settling unit into silts and clay from the suspension cloud. Right, TGA calcite and aragonite analyses. 2 polished slab of the inset of (1). These fine-to-medium sand intervals show several climbing-ripple intervals. At a different oriented section, these ripples can be easily interpreted as HCS and lead to a tempestite interpretation

ellipsoid. The fissures are often a few $\mathrm{cm}$ offset in cracks, demonstrating soft-sediment deformation just after their origin. The origin of the injected sand is probably related to the deposition of the basal coarse sand bed. Although the coarse layers are cross-bedded, reliable current directions could not be measured due to its lateral channel-fill characteristics. On perpendicular cross-cuts, trough infill migration is toward the SW. 

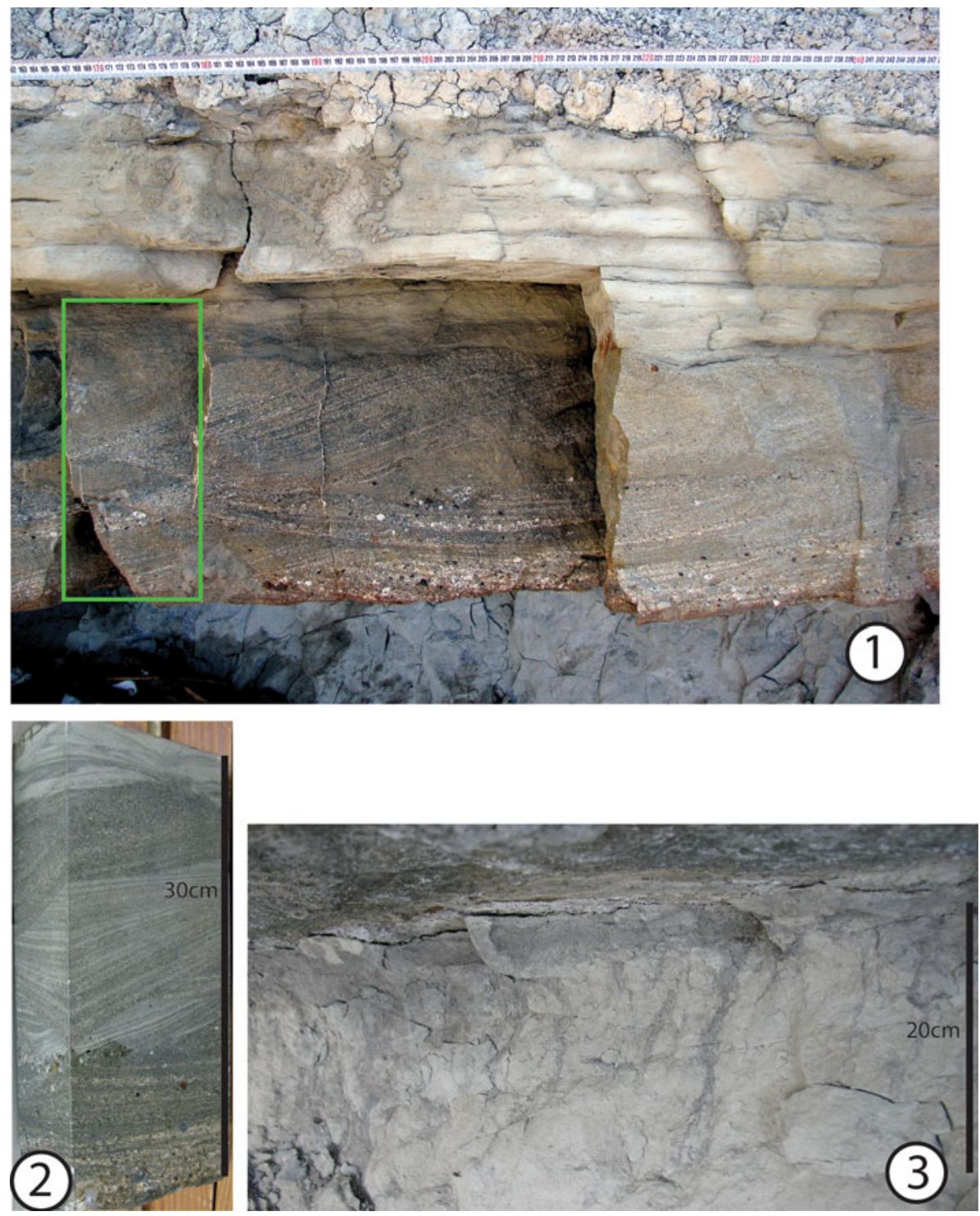

Fig. 10 Tsunamiite Ts2 with two coarse layers displaying trough cross-bedding (1) Graded trough crossbeds and inset of (2). 2 On perpendicular planes polished block of the lower bed of Ts2, taken at the green inset in (1). The two orientations made it possible to infer a paleocurrent direction toward the SW. Black chert, limestone and limnocardium bivalves are the main components. 3 Top of the mudstones directly underlying Ts2, containing many 5- to 15-cm-long fissures filled with coarse sand. The planar shape of the fissures makes it unlikely that these are plant roots in a soil, as suggested by Roveri et al. (2005)

\subsection{Ts3 (tsunamiite 3 )}

The highest multiple-layered graded layer occurs near the top of the Colombacci fm, about $1.5 \mathrm{~m}$ below the base of the shore-face Trave sandstones (Figs. 6, 12). The layer can be subdivided in two graded, gravelly to coarse sand beds. The lower bed Ts3a is a 5-m-wide 

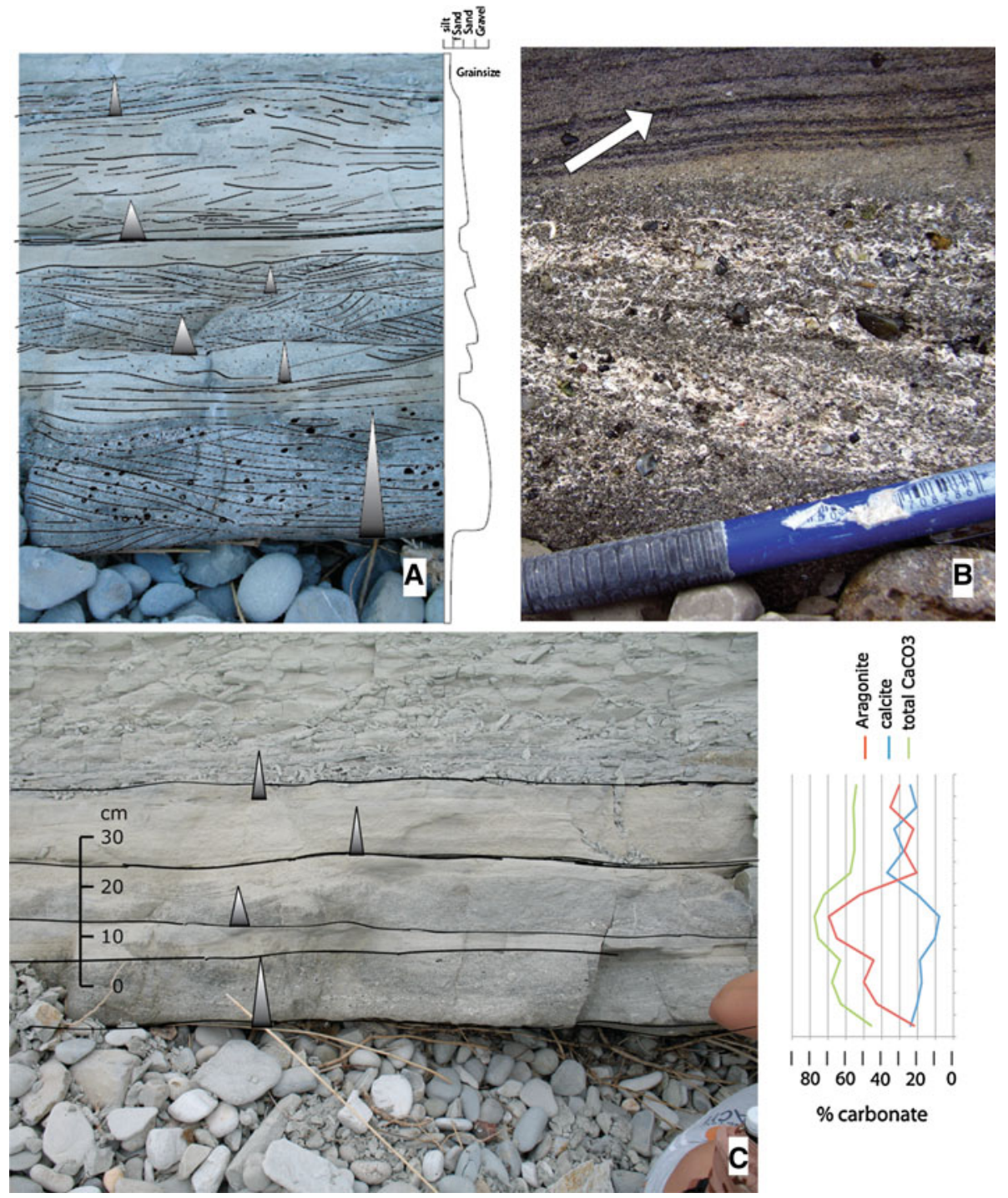

苋

| | |

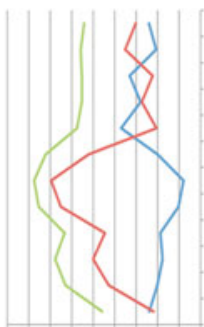

$1|1| 1|1| 1 \mid$

$80 \quad 60 \quad 40 \quad 20$

$\%$ carbonate

Fig. 11 Tsunamiite Ts2 with two coarse layers displaying trough cross-bedding (a) Outlined foreset lamina and graded beds. At least 6 graded beds visible in Ts2. b Details of the coarsely laminated cross-bedding of the lowest bed. Black chert, limestone and current-stable bivalves are the main components. Arrow points to lamina with abundant plant debris in the finer grain size interval between the coarse beds. $\mathbf{c}$ Ts 2 layer with two tabular trough cross-bedded beds. The many broken bivalve shells cause the high aragonite content compared to the mudstones below

channel, downcutting into the underlying mudstones. The upper bed Ts $3 \mathrm{~b}$ is over $25 \mathrm{~m}$ wide and cuts down into both the lower bed and the underlying mudstones where the lower bed is terminated. Ts $3 b$ displays several 1- to 2-m-wide subchannels with a very coarse base (pebbles $>10 \mathrm{~cm}$ ). The thickness of Ts 3 varies in outcrop from 5 to $45 \mathrm{~cm}$, and the entire layer pinches out completely over $25 \mathrm{~m}$. Both beds display typical medium size, 
high-angle trough cross-bedding. The top of bed Ts3a grades into medium sand and displays at the top symmetrical wave ripples, similar to symmetrical ripples at the top of bed 1 of Ts1. Because the ripples show unidirectional foreset laminae in cross section and do not display the typical alternating bidirectional foreset laminae of wave-oscillation structures, the ripples are probably produced on top of the graded layer by short oscillatory water movements. The wave-ripple surface forms a shallow 2-m-wide depression, which is filled with a graded $<5 \mathrm{~cm}$ fine sand to silt layer. The composition of the gravel and sand grains include the same rounded white vein-quartz pebbles and dark chert pebbles as Ts1 and Ts2. Bivalve shell fragments, abundantly present in Ts2, are almost absent. Micritic limestone sand grains form a major component, as shown by the high $\mathrm{CaCO}_{3}$ content. The homogenous silty mudstones underlying Ts 3 contain conspicuous cracks not present in the mudstones above Ts3. These cracks all depart from the base of Ts 3 but, in contrast to the dark fissures below Ts2, are not filled with sand. We interpret these cracks as seismically induced just before deposition of Ts3.

\subsection{Tsunamiites in the Feos formation, Nijar Basin, SE Spain}

Fortuin and Dabrio (2008), Fortuin and Krijgsman (2003) found ample evidence for seismic activity and ground movements in Lago Mare sediments of the Feos formation in the north-eastern part of the Nijar Basin, SE Spain, in the form of fissures with sand

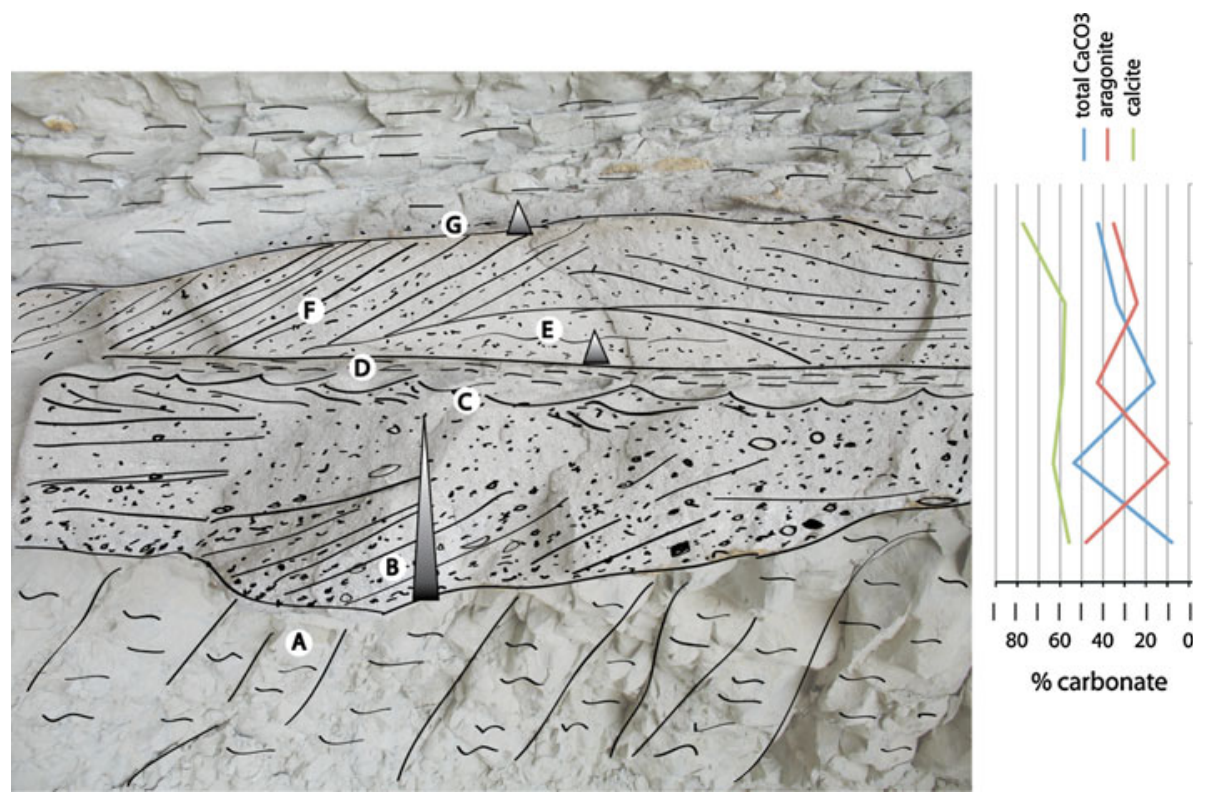

Fig. 12 Tsunamite Ts3. (1) Channel with SW-NE axis. Foreset migration suggests current direction to the SW. a offshore mudstones, with many parallel cracks that terminate against the base of Ts3. These were probably seismically induced. b Graded lateral channel fill, c symmetric small ripples on top of the channel fill b. d silt interval, settled between the coarse beds $\mathbf{b}$ and e. e Large ripple, finer-grained than f. f Second coarse-grained interval, with trough cross-bedding. g Topmost fine sand silt graded bed, probably representing the final settling from the suspension cloud 
dykes, slumps, and other soft-sediment deformation features, synsedimentary faults, liquefaction, and displacements that were induced by earthquakes along nearby large faults active in late Messinian times: the E-W running Cabrera normal fault in the north (active in Late Messinian) and the SW-NE running Carboneras strike-slip fault in the south (Fig. 7). Both faults form the boundary of the semi-enclosed Nijar Basin. In the LLM, Fortuin and Dabrio 2008 describe fissures filled with sand (sand dykes), which are broken and similar to the fissures below Ts2 in the Trave section. Also in LLM, Fortuin and Dabrio 2008 found sets of obliquely oriented, coarse sand injections crosscutting laminated strata (Fig. 13). These sand dykes are clearly conjugate and terminate against the directly overlying, graded sand layer, which Fortuin and Dabrio 2008 interpret as seismically triggered. The sand in the sand dykes is coarser than the immediately overlying sand layer, which they interpret as having a different provenance. However, the sand injections could have also occurred during an early high-energy phase of the sand transport still containing coarser particles, which were injected in the fissures shortly after the seismic shaking opened them and before the deposition of the remainder of the sand layer. The conjugate fissures run parallel to the Cabrera fault, and the opening of the fissures appears induced by NS horizontal ground movement caused by the earthquakes along the Cabrera fault (Fig. 7).

In the outcrop near Los Feos, the sand layers capping the conjugate sand-filled fissures are not a single graded layer but come in pairs and triplets (Fig. 13). The first sand layer is followed at regular distances by a second (and often by a third or fourth) thinner and finergrained sand layer. The regular spacing and thinning/fining upward suggests that these series of sand layers are genetically linked and are indirectly induced by the same tectonic event.

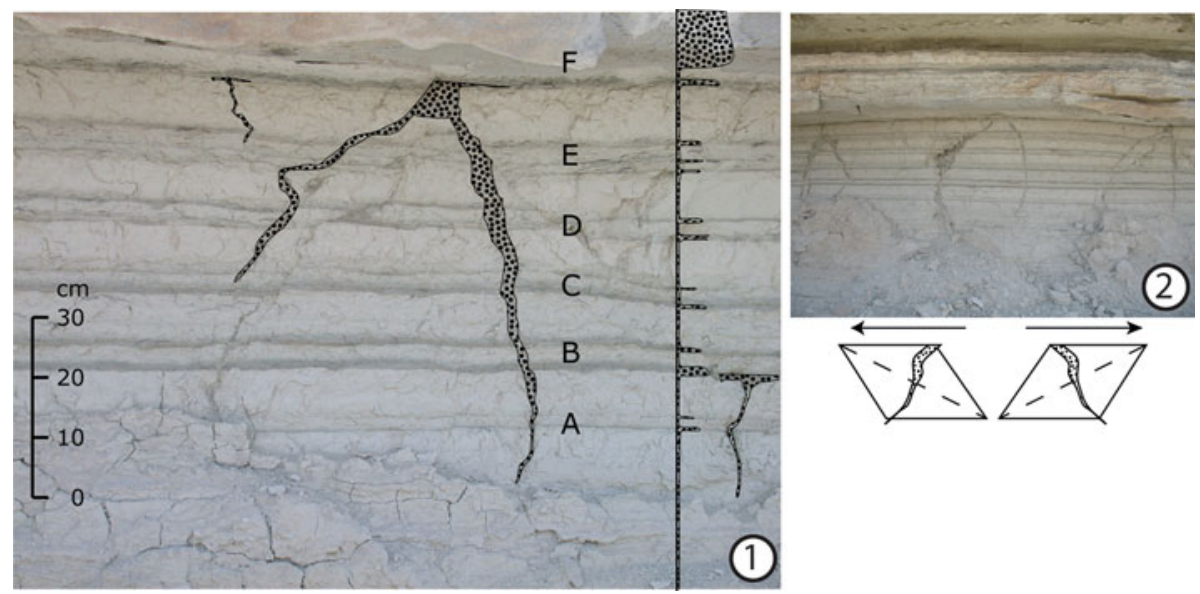

Fig. $13 A-F$; Cyclic sets of graded sandstone layers in fine-grained Lago Mare marls of the Feos formation. The deposition of the sets is related to fault movements along the Cabrera fault. The regularity of the sets suggests they are tsunamiites, probably caused by seiches in the semi-enclosed Nijar Basin. 1 Cycles of pairs and triplets of sandstone layers, decreasing in thickness in each cycle. Sedimentary dykes, filled with sand from the overlying sand layer, the lowest of each cycle, underlie several cycles. 2 Three conjugate sets of sand dykes. The fissures are opened by horizontal surface movements (arrows) from an earthquake along the Cabrera fault, which is running parallel to the strike of the fissures 


\section{Discussion}

\subsection{Occurrence and expected sedimentary architecture of offshore tsunamiites}

A tsunami triggered by a sudden convulsive event consists of a wave train of numerous waves. They are comparable to the concentric waves produced by a pebble thrown into a pond (Fig. 14), but there are important differences: The wave height to length ratio is much larger than tsunami waves in an open ocean, which behave like a "very shallow-water wave' i.e., wavelength is much longer, and amplitude much smaller, than water depth. In the far field, the pond ripples increase in length and decrease in height while picking up speed. Tsunami waves have wave lengths in the open ocean ( $>3 \mathrm{~km}$ water depth) of up to many hundreds of kilometers and wave periods up to $1 \mathrm{~h}$ but are there of limited height $(<1 \mathrm{~m})$.

The propagation velocity $v$ of such waves is given by: $v=\sqrt{d \cdot g}(d=$ depth, $g=$ gravity constant) which for an open ocean (3 km depth) is $\sim 500 \mathrm{~km} / \mathrm{h}$. The time for passage of one entire wave can therefore be between 0.25 and $1 \mathrm{~h}$, as is clearly seen on data from tidal gauges of the December 2004 tsunami in the Indian Ocean ${ }^{1}$ (Fig. 15). When a tsunami wave approaches the shore, the front slows down and grows in height, conserving its energy, but the passage of the entire wave takes the same amount of timeabout $1 / 4$ to $1 \mathrm{~h}$. This stands in contrast to the far field waves of a large storm event, with wavelengths $<100 \mathrm{~m}$, resulting in a multitude of waves per storm event with a wave period measured in seconds.

This contrast has profound implications for the resulting sedimentary deposits at shallow lower shore-face to offshore (10-100 m) water depths. Storm waves basically produce short-term, large oscillatory currents on the seafloor at this depth. The passage of a storm event will lead to a tempestite deposit, a single graded bed, characterized by erosion of the seafloor, subsequently filled with a lag deposit, followed-at waning wave energyby a graded sandy deposit showing hummocky cross-stratification (HCS) indicative of oscillating currents on the seafloor (Fig. 15).

Tsunami waves in the near-shore run-up and backflow phase produce oscillatory water movements that can be best described as "mini or pseudo-tidal surges" [also named "shuttle movements"(Shiki et al. 2008)] with up-flow currents running for a prolonged time toward the coast, and backflow currents subsequently toward the sea for an comparable amount of time. Visually, such 'waves' are comparable to tidal bores (Fig. 16) and pack much more energy than normal surface waves (swells) of comparable height. This is probably the reason that the sight of the approaching tsunami wave does initially not alarm people standing on a beach. Tidal bores occur in estuarine areas where the day-to-day differences between high and low tides are very large and already cause energetic tidal currents. Additional tsunami waves would most likely not leave a sedimentary deposit different from tidal deposits in such estuarine environment. In coastal areas with long straight shorelines, on the other hand, where daily tidal water movements are much smaller, a tsunami deposit is much more likely to occur. In such environment, the passage of the tsunami waves - as a pseudo-tidal bore-will most likely leave sedimentary deposits discernible from normal offshore mudstones.

The arrival of a train of shallowing tsunami waves, which transfer the waves into shortduration pseudo-tidal surges, will ultimately result in a single stack of multilayered, overall graded deposit at shallow-to-deep offshore depths. Each of the surges produces

\footnotetext{
${ }^{1}$ http://www.nio.res.in/data_info/tide_gauge.htm.
} 


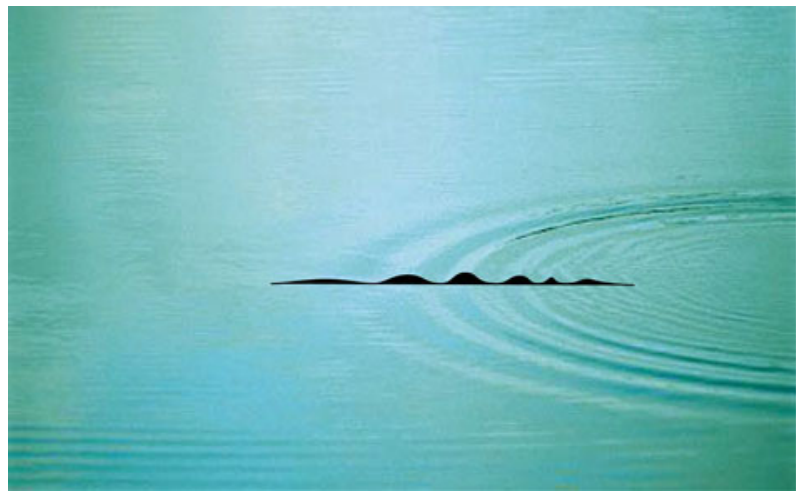

Fig. 14 Ripples in a pond, triggered by a stone thrown in the pond. A train of waves radiates outward and can be used as a crude analog for tsunami wave trains, although the height-to-length ratio of the waves is much larger here. Note that the leading wave is longer and lower and therefore travels faster that the second wave

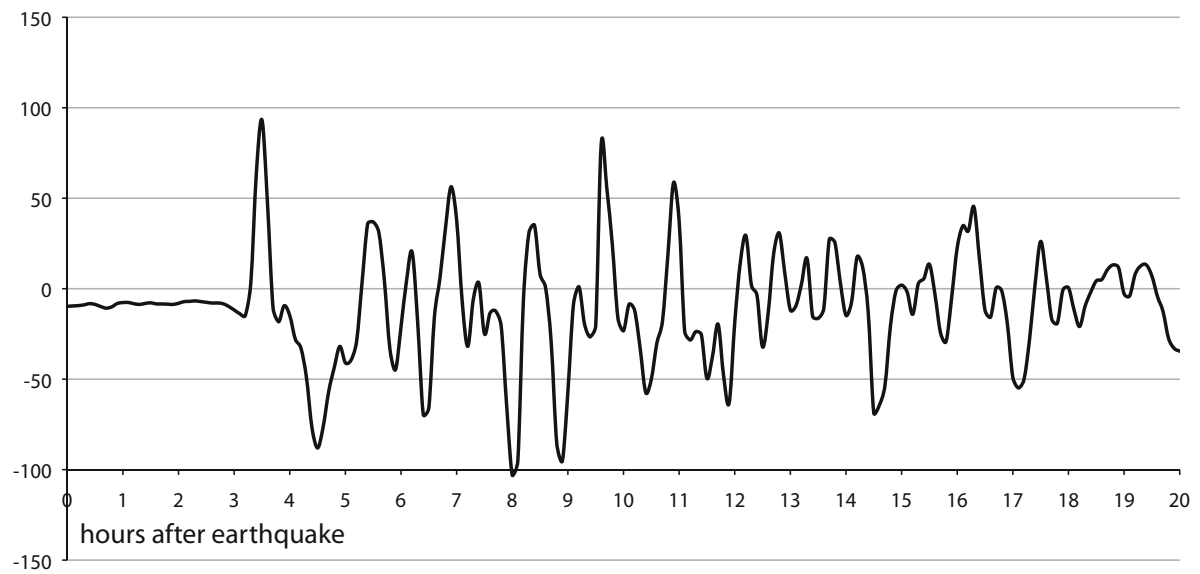

Fig. 15 Sea-surface height of the 2004 Indian Ocean tsunami measured on a tidal gauge near Tuticorin, India, detrended for tidal effects. Note that the tsunami consists of many individual waves that decrease in height over time. The passage of each wave lasted here up to $1 \mathrm{~h}$

unidirectional currents, either in onshore or in offshore direction, which differ fundamentally from the oscillation currents produced by storm waves. The first tsunami wave (surge) erodes into underlying soft offshore mudstones and should leave sole marks (flutecasts and tool marks) that can be very similar to those produced at the base of turbidites. Successive wave (surge) arrivals will erode into the top of the previously deposited surges. Due to waning strength of the tsunami waves, each following surge will have less energy and will be less capable of downcutting into the former surge layers and be finer-grained (Fig. 15).

As with homogenite 'B' (Cita 2008), the up-rush and in particular the backflow of the tsunami surge will erode a large amount of sediment and bring it into suspension. Because of its high density and supported by backflow currents, the sediment-laden suspension will 


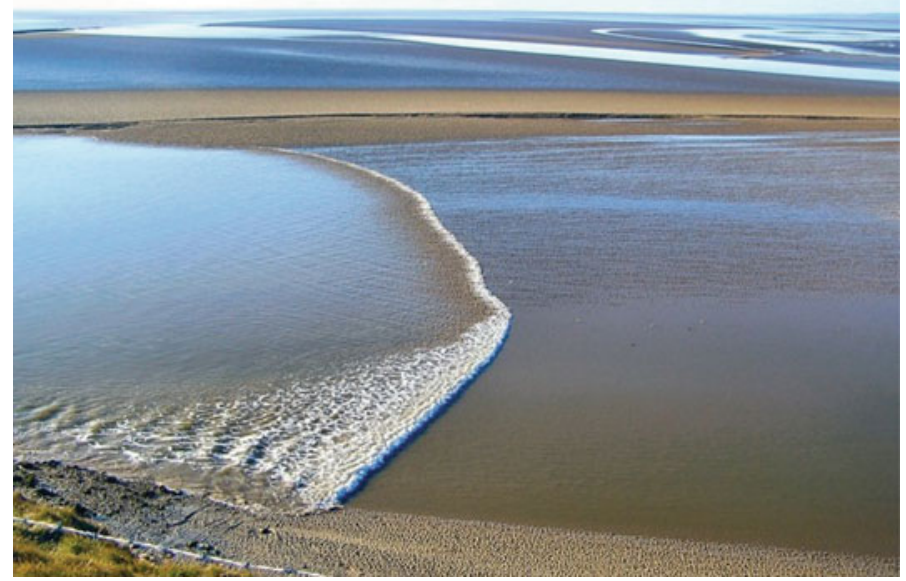

Fig. 16 A tidal bore in the Kent estuary. The bore surge is comparable to the tsunami waves approaching a shallowing shore and may produce similar current patterns. Copyright: Arnold Price

move downslope as gravity flow. The following up-rush surge will slow down the gravity flow, leading to rapid sedimentation of the suspended sand. This phase is often represented by climbing-ripple sets. The next backflow surge of the next tsunami wave will initially be strong enough to erode down into the previously deposited layer of sediment and, when slowed down by the next up-rush surge, lead the next cycle of deposition of suspended sediments.

A complete offshore tsunami deposit should thus reflect the passage of a series of tsunami waves, in general waning in strength. Each of these waves-or surges-should reflect a sequence of erosion, transport, and deposition (Dawson and Shi 2000).

The expression (architecture) of the resulting tsunami deposits may be variable with water depth, wave height, or size, the confinement of the body of water where the tsunami occurred [a narrow lake or seaway, a confined sea (Mediterranean, Gulf of Mexico), bottom topography (Shiki and Cita 2008)], and availability of unconsolidated sediment. In general, tsunami surges carry a high sediment load, when substantial amounts of sediments were eroded from either the seafloor or coastal areas, as observed near Aceh Banda in Indonesia after the 2004 tsunami (Fig. 1), or the type 2 homogenites (turbidites) of the Santorini tsunami (Cita 2008; Shiki and Cita 2008).

The Chicxulub impact-related tsunamiites (Smit et al. 1996) in the Gulf of Mexico and the Proterozoic tsunamiites in the Hamersley Basin (Hassler et al. 2000) characteristically display rather thick climbing-ripple intervals often followed by a graded but visually homogenous silt-clay tail (Smit et al. 1996), attesting to this high sediment load.

A typical tsunamiite (if such type of deposit exists) (Fig. 17) should therefore contain a number of characteristic items (see below), preferably a combination of these, reflecting the above conditions.

An offshore Tsunamiite:

1. Stands out from the sedimentary sequence above and below and should not be the culmination of a clearly observable sedimentary trend.

2. Should reflect the repeated high-energy input of recurring powerful currents. 
3. Consists of a series of graded beds, each one reflecting passage of one of the tsunami surges. As the initial waves are the largest, the lowest beds will usually be the coarsest, although as the Indian Ocean tsunami learned (Fig. 15) that the second or third one is often the largest.

4. Each of the higher beds should in general indicate less current energy and show a thinning of beds and an overall decrease in grain size, but see 3 .

5. Reflects the high sediment load in suspension in the water from eroded areas, although the end product is dependent on the characteristics of the eroded sediment (climbing ripples, high-density flows).

6. Should not display typical hummocky cross-stratification (HCS), although in the waning stages, short-term oscillatory movements in the water may occur.

7. May contain evidence of the triggering event, such as earthquake-induced softsediment deformation below, but not above the tsunamiite; volcanic ashes; impact ejecta.

8. Be synchronous in different environments when found over a large region.

9. May contain debris backwashed from back-barrier supra-tidal areas flooded by the tsunami. This may include abundant plant debris.

10. Could display a burrow fabric at the top, consisting initially of back-burrowing animals like crabs and shrimps, followed by a normal multitiered burrow fabric that is normal for the local seafloor. Back-burrowing animals may also penetrate into the top of the lower layers deposited by preceding tsunami surges because there is sufficient time for these [up to $1 \mathrm{~h}$, see Fig. 3)], but not enough time to develop a normal, tiered burrow fabric.

It is unlikely that in any tsunamiite, all of the above criteria will be met, but the combination of a number of these may identify a tsunamiite. Note however that the above criteria in isolation do not provide proof of a tsunami deposit (Shanmugan 2011). Some of the above criteria are by itself also valid for gravity flows or turbidity currents or tempestites.

Tsunami wave deposits (tsunamiites) should be different from tempestites (Fig. 17) in many aspects. Because they can reach greater depths (depending on the distance from and magnitude of the triggering event), they stand out from storm events. The frequency of unusually large storm events [taken the data from hurricane deposits around the Gulf of Mexico (Donnelly and Woodruff 2007)] will be one catastrophic event every 10-250 years at a single location. In offshore sedimentary archives, prone to such storm events, tempestite deposits should therefore frequently occur, as long as the depositional area remains at a suitable depth. Such depositional intervals are known, e.g., from transgressive base of the Cretaceous Del Rio fm of the Western Interior Seaway in the United States (Lock et al. 2009), where the tempestites are stacked upon one another, and display characteristic large HCS.

The complex sandstone beds in numerous outcrops at the KPg boundary around the Gulf of Mexico are clear examples of tsunamiites and share many-and often all—of the above-indicated characteristics (Smit 1999; Smit et al. 1996; Smit 2010 in preparation). Striking features in these tsunamiites are thick $(10-40 \mathrm{~cm})$ backflow direction climbingripple intervals, displaying decreasing current strength upwards, just before the up-rush of the next incoming tsunami surge.

Shanmugan (2011) states that single sedimentologic criteria alone cannot distinguish between storm (hurricane) and tsunami event deposits. He summarized the criteria of reported tsunami-produced sediment beds in a wide variety of environments, but none of 
$\Rightarrow \theta$
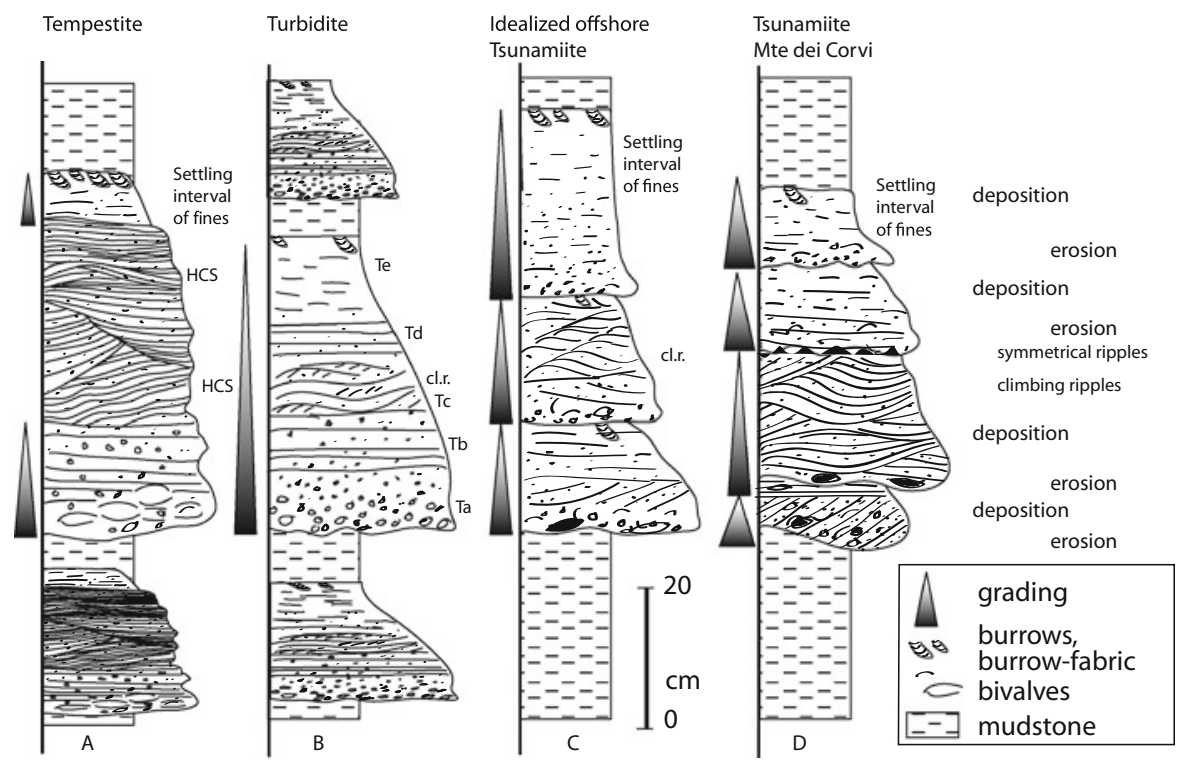

Fig. 17 Comparison of characteristic event deposits. a A typical tempestite, showing a sequence of erosion in the seafloor: Deposition of a coarse, graded 'lag' deposit of debris and shells that are often double-valved because they were washed out alive, followed by a medium-sand interval containing HCS cross-bedding and often not graded. The final phase is the settling of fine sand, silt and mud after the storm has passed. Tempestites are rarely a single bed and occur in sets. b A typical turbidite, showing a single Bouma Ta-Te sequence. c Tsunamiite, composed of many graded layers, reflecting a series of erosion, transport and deposition cycles. d Composite of the Ts1-Ts3 from the Colombacci formation. All three types of event deposits often terminate in a graded fine sand-silt-clay interval, when the suspended fine fractions are settling on the seafloor with reduced current energy

the tsunami-related sedimentary characteristics are diagnostic on its own, and he concluded that up till now, it is not possible to make a distinction between storm- and tsunami eventproduced deposits. The wide variety of observed cross-beds [low-angle, HCS, climbing ripples, (Morton et al. 2007)], planar beds, and normal and inverse grading reported from tsunami beds are very similar to those of turbidites, mass flows or debris flows and tempestites. Erosional bases are also characteristic for tempestites and debris flows/ turbidites. Anomalous coarse sand layers (event beds) are also reported from storm deposits. Yet, the vast majority of the described characteristics are from coastal, shore-face to coastal plain environments. Very little is reported from the (shallow) offshore environment.

The three graded coarse sandstone beds in the Messinian Trave succession are similar in texture, structure, and the composition of the sand grains, and it is therefore likely that they share a common origin. The three beds were earlier described by Roveri et al. (2005) as (op cit): "thin, coarse grained bioclastic sandstone bodies containing (brackish water) Limnocardium, having an erosional base, displaying normal and inverse grading, medium scale cross-beds at the base, sharply overlain by fine-grained sandstones with HCS". These sandstone bodies are supposedly rhythmically alternating with thick mudstone bodies. 
Roveri et al. (2005) interpreted such strata as common in the shallow marine record and as "lobes deposited from high-density gravity flows generated by fluvial floods, or alternatively, by severe storm events".

However, a rhythmic occurrence of the three coarse sandstone beds is far from obvious in the Trave section; their occurrence is anomalous and random. The angular clasts and admixture with Limnocardium fragments do not argue for a fluvial related origin, but for a local, coastal, source of these components. A high-density gravity flow is an acceptable explanation for some of the individual graded gravelly and poorly sorted sublayers. The grain-supported texture and high-angle, trough cross-bedding of other sublayers argues for deposition by traction currents. However, the atypical, multistoried, repeatedly graded cross-bedded stack of sublayers of all three beds argues for another origin of the layer as a whole. Roveri et al. (2005) support their fluvial origin interpretation by the interpretation of coarse sand-filled "root traces" just below the second sandstone bed Ts2, as an indication for emergence. However, as mentioned earlier, we interpret these "traces" not as tubular root traces, but more planar, seismically induced fractures and cracks, which allowed sand from the sand-laden tsunami-induced current or sand of the overlying sandstone bed deposited by the first tsunami surge to penetrate into those fissures as sedimentary dykes. A similar situation is discussed below for the Feos seismites/tsunamiites.

The alternative interpretation by Roveri et al. (2005) as severe storm deposit remains another possibility. The many thin, fine-grained turbidites interbedded in the lower part of the san Donato mudstones are most likely triggered by either distal storm events or distal earthquakes and indicate deposition in a rather deep offshore environment. However, the three Ts1-Ts3 beds are very different from those. The supporting evidence for storm deposit in Ts1-Ts 3 is the interpretation of the cross-bedding in the upper part of the beds as HCS.

HCS is often difficult to establish, and controversial interpretations as storm deposits are based on improper interpretation of cross-beds as HCS (Fig. 9). Shanmugan (2011) warns that the origin of HCS is controversial. However, he allows for a broad interpretation of HCS in general. He cites (Mulder et al. 2009) who interpret anti-dune-like ripples as HCSlike structures in deep-water turbidites. Identical structures are found at the base of Chicxulub impact tsunamiites at la Lajilla, Mexico (Smit et al. 1996), but those are clearly not related to storm activity. At the K/Pg boundary at Brazos River, Texas, Smit et al. 1996 disagree about the interpretation as HCS of cross-bedding in the upper part of the $\mathrm{K} / \mathrm{Pg}$ sandstone bed (Gale 2006; Yancey 1996). Cross sections perpendicular to the current direction of climbing-ripple sets were here misidentified as HCS. HCS is a sedimentary structure produced by large, but short-term oscillatory currents caused by passage of large waves. Very long tsunami waves produce longer-term oscillations, producing tidal-like, opposing direction currents that will produce different cross-bedding structures such as climbing ripples because of the high sediment suspension load of the currents.

Because an interpretation of sandstone beds as produced either by storm (tempestite) or tsunami event often hinges on proper identification of HCS, we urge for a careful interpretation of such cross-bedding structures.

The grain size analysis in the colombacci-san Donato mudstones demonstrates that the occurrence of the Ts1-Ts 3 tsunamiites is not related to a trend in the under- and overlying offshore mudstones. This argues against a connection of Ts1-Ts3 to a gradual shift in facies, such as caused by climate-related shifts in base level as suggested by Roveri et al. (2005). 
It is the combination of criteria that makes interpretation of the Ts1-Ts3 beds as tsunamiites likely: (1) the beds stand alone in the mudstone sequence, without preceding facies shifts toward the sandstone beds. (2) They are composed of a stack of graded and cross-bedded sublayers, each eroding into the preceding one and each connected to an individual tsunami wave surge within the tsunami event. (3) They display climbing-ripple sets rather than HCS in the top of each sublayer, in particular, near the end of the backflow stage when suspension-laden tsunami currents lose energy because of the next tsunami wave up-surge. (4) They are linked to earthquake-produced fissured in the seafloor, indicating the triggering event of the tsunami event. The architecture of Ts1-Ts 3 satisfies a good number of the above-mentioned criteria and leads us to the conclusion that all three beds are probably offshore tsunamiites.

The graded sand layers in the Messinian Feos formation of southern Spain differ (Figs. 7, 13) in aspect from the Ts1-Ts3 layers in the Trave section. Fissures were observed below graded this sandstone layers (Fortuin and Dabrio 2008) and were interpreted as sedimentary dykes induced by seismic shaking from displacement along the Carboneras fault and filled with sand from the overlying tsunami-induced sandstone beds. This situation is analogous to the dark fissures underneath Ts 2 in the Trave section. The sand layers are typical for turbidites, they are graded and contain flute-cast at the base, and they were interpreted by Fortuin and Dabrio (2008) as turbidites directly triggered by the earthquake that caused the sand-filled fissures. However, the turbidites are not single, but come in sets of pairs and triplets, decreasing in grain size and thickness upwards. It seems unlikely that the second and third (fourth) sand layers are directly triggered by (regularly reoccurring) aftershocks, and therefore, we interpret the occurrence these turbidite sets not as directly seismically induced but as a seismically induced tsunami or seiche event. The origin of the tsunami waves is linked to the origin of the sand-filled fissures i.e., large vertical movements along large Cabrera thrust fault.

The origin of the Ts1-Ts3 tsunamiites in the Trave section can be found in large NE vergent thrust faults, like the Sibillini thrust front (Roveri et al. 2005), that were active on the western margin of the large Laga foreland basin (Fig. 3), because of the compression of the Laga foreland basin due to movement of the Apennines toward the Apulian platform in the late Messinian (Govers et al. 2009). The Ts1-Ts3 tsunamites are located on the eastern margin of the Apulian platform, favorably located to receive large tsunamis from the Sibillini thrust front. The components of Ts1-Ts3 are dominated by bioclastic, shallow-water limestones of various ages, readily available on the shallow-water Apulian platform underlying the Adriatic Sea. Abundant plant debris in Ts2 also argues for backwash from an emerged area on the Apulian platform. Similar abundant plant remains were found in of Mimbral, Mexico, in the tsunamiites triggered by the Chicxulub impact. The folded and up-thrust sedimentary sequence west of Ancona is dominated by the deep-marine Umbre-Marche pelagic sequence (Alvarez and Montanari 1988; Montanari et al. 1997) and therefore an unlikely source of the components in Ts1-Ts3. The trough cross-bedding of the lowest bed of Ts2 show a paleocurrent direction toward the SW (Fig. 11). Paleocurrent directions toward SW were also measured on a turbidite in the underlying Tortonian Corve sequence (Montanari et al. 1997). These paleocurrent directions demonstrate a north-easterly source on a NE-SW slope on the Apulian platform margin. Alternatively, the triggering faults can be sought in the many thrust faults off the present Adriatic coast. However, these are mostly active in post-Messinian Plio-Pleisticene times and thus an unlikely source of the tsunami waves. 


\section{Conclusions}

Three 10- to 80-cm-thick coarse clastic beds in the late Messinian Colombacci formation in the Trave section at Monte Dei Corvi, Italy, are interpreted as offshore tsunamiites (Ts1-Ts3) because of the combination of following characteristics:

1. They occur as unique coarse clastic layers within monotonous mudstones without any indication of a trend in the sediments pre- or post-dating the layers.

2. They form tabular or channeled layers that can be followed (Ts1) over several hundred meters and are not confined to narrow (fluvial) channels.

3. They are each built of a stack of 4-6 graded sublayers, each decreasing in grain size and thickness and therefore in energy. Each of the graded beds erodes into the previously deposited beds or in the mudstones below its base.

4. They are cross-bedded in dm-thick high-angle trough cross-beds in the coarse basal parts, with current direction consistent with tsunami backsurge.

5. They contain climbing-ripple intervals in fine-to-medium sand and the same grain size as in a Bouma Tc interval, which points to deposition under waning current strength and a high suspension load, consistent with the erosion of large amount of clastic material from near-coastal areas.

6. They contain bivalves that are eroded from near-shore areas by the tsunami backwash but do not contain double-valved shells as is common in tempestites.

7. They contain layers of fine plant debris, probably derived from water-saturated plant material buried (as peat) in supra-tidal lagoons, transported to offshore regions by the tsunami backsurge.

8. They are underlain in one case by a meshwork of sand-filled planar fissures in the underlying mudstone. These are probably not root traces indicating a soil, because in cross section, the fissures are not round or elliptical. These fissures may be related to the large earthquake triggering the tsunami vent.

9. Regular spaced sets of doublets and triplets of graded thin sand layers, each decreasing in thickness and grain size, intercalated in the Lago Mare mudstones of the Feos formation in the Nijar Basin, Spain, are interpreted as tsunamiites deposited by oscillating seiche/tsunami-driven currents, which cause cyclic water movements decreasing in strength. Vertical movements along the nearby Cabrera fault, active in late Messinian times, trigger these oscillating seiches.

Acknowledgments We thank Luuk Kleipool, Lisa Meijer, and Mart Zijp for help in the field. Martin Konert is acknowledged for help with the TGA and grain size analyses. Two anonymous reviewers provided a great help in getting the paper in correct shape.

Open Access This article is distributed under the terms of the Creative Commons Attribution Noncommercial License which permits any noncommercial use, distribution, and reproduction in any medium, provided the original author(s) and source are credited.

\section{References}

Alvarez W, Montanari A (1988) The Scaglia limestones (Late Cretaceous-Oligocene) in the northeastern Apennines carbonate sequence: stratigraphic context and geological significance. In: Premoli Silva I, Coccioni R, Montanari A (eds) The Eocene-Oligocene boundary in the Marche-Umbria Basin (Italy). International Subcommision on Paleogene Stratigraphy of the International Union of Geological Sciences, Ancona, pp 13-30 
Bond G, Showers W, Cheseby M, Lotty R, Almasy P, deMenocal P, Priore P, Hajdas HCI, Bonani G (1997) A pervasive millenial scale cycle in North Atlantic Holocenen and glacial climates. Science 278:1257-1266

Bourgeois J, Hansen TA, Wiberg PL, Kauffman EG (1988) A tsunami deposit at the Cretaceous-Tertiary boundary in Texas. Science 241:567-570

Cita MB (2008) Deep-sea homogenites: sedimentary expression of a prehistoric megatsunami in the eastern Mediterranean. In: Shiki T, Minoura K, Tsuji Y, Yamazaki T (eds) Tsunamiites. Elsevier, Amsterdam, pp 185-202

Dawson AG, Shi S (2000) Tsunami deposits. Pure Appl Geophys 157:875-897

Dawson AG, Steward I (2007) Tsunami deposits in the geological record. Sediment Geol 200:166-183

Dawson A, Stewart I (2008) Offshore tractive current deposition: the forgotten tsunami sedimentation process. In: Shiki T, Minoura K, Tsuji Y, Yamazaki T (eds) Tsunamiites. Elsevier, Amsterdam, pp 153-162

Dawson AG, Long D, Smith DE (1988) The Storegga slides: evidence from eastern Scotland for a possible tsunami. Mar Geol 82:271-276

Donnelly JP, Woodruff JD (2007) Intense hurricane activity over the past 5, 000 years controlled by El Niño and the West African monsoon. Nature 447:465-468

Fortuin AR, Dabrio CJ (2008) Evidence for Late Messinian seismites, Nijar Basin, south-east Spain. Sedimentology 55:1595-1622

Fortuin AR, Krijgsman W (2003) The Messinian of the Nijar Basin (SE Spain): sedimentation, depositional environments and paleogeographic evolution. Sediment Geol 160:213-242

Gale A (2006) The Cretaceous-Palaeogene boundary on the Brazos River, Falls County, Texas: is there evidence for impact-induced tsunami sedimentation? Proc Geol As 117(2):173-185

Govers R, Meijer P, Krijgsman W (2009) Regional isostatic response to Messinian Salinity Crisis events. Tectonophysics 463:109-129

Hassler SW, Robey HF, Simonson BM (2000) Bedforms produced by impact-generated tsunami, $2.6 \mathrm{Ga}$ Hamersley basin, Western Australia. Sediment Geol 135:283-294

Hilgen F, Kuiper K, Krijgsman W, Snel E, van der Laan E (2007) Astronomical tuning as the basis for high resolution chronostratigraphy: the intricate history of the Messinian Salinity Crisis. Stratigraphy 4:231-238

Husing SK, Hilgen FJ, Abdul Aziz H, Krijgsman W (2007) Completing the Neogene geological time scale between 8.5 and 12.5 Ma. Earth Planet Sci Lett 253:340-358

Izett GA, Cobban WA, Obradovitch JD, Kunk MJ (1993) The Manson impact structure: 40Ar/39Ar age and its distal impact ejecta in the Pierre shale in Southeastern South Dakota. Science 262:729-732

Konert M, VandenBerghe J (1997) Comparison of laser grain size analysis with pipette and sieve analysis: a solution for the underestimation of the clay fraction. Sedimentology 44:523-535

Krijgsman W, Fortuin AR, Hilgen FJ, Sierro FJ (2002) Astrochronology for the Messinian Sorbas basin (SE Spain) and orbital (precessional) forcing for evaporite cyclicity. Sediment Geol 140:43-60

Lock BE, Butler RW, Franklund RT (2009) Tempestite sedimentation: an example from the Del Rio formation of West Texas. Trans Gulf Coast As Geol Soc 59:463-476

MacInnes BT, Bourgeois J, Pinegina TK, Kravchunovskaya EA (2009) Tsunami geomorphology: erosion and deposition from the 15 November 2006 Kuril Island tsunami. Geology 37:995-998

Manzi V, Roveri M, Gennaria R, Bertinib A, Biffi U, Giunta S, Iaccarino SM, Lanci L, Lugli S, Negri A, Riva A, EdoardoRossi M, Taviani M (2007) The deep-water counterpart of the Messinian Lower Evaporites in the Apennine foredeep: the Fanantello section (Northern Apennines, Italy). Palaeogeogr Palaeoclimatol Palaeoecol 251:470-499

Montanari A, Beaudoin B, Chan L, Coccioni R, Deino A, DePaolo DJ, Emmanuel L, Fornaciari ES, Kruge M, Lundblad S, Mozzato C, Portier E, Renard M, Rio D, Sandroni P, Stankiewicz A (1997) Integrated stratigraphy of the middle to upper Miocene pelagic sequence of the Cònero Riviera (Ancona, Italy). In: Montanari A, Odin GS, Coccioni R (eds) Miocene stratigraphy: an integrated approach. Developments in paleontology and stratigraphy vol 15, pp 409-450

Morton RA, Gelfenbaum G, Jaffe BE (2007) Physical criteria for distinguishing sandy tsunami and storm deposits using modern examples. Sediment Geol 200:184-207

Mulder T, Razin P, Faugeres J-C (2009) Hummocky cross-stratification-like structures in deep-sea turbidites: upper Cretaceous Basque basins (Western Pyrenees, France). Sedimentology 56:997-1015

Norris RD, Firth J, Blusztajn JS, Ravizza G (2000) Mass failure of the North Atlantic margin triggered by the Cretaceous-Paleogene bolide impact. Geology 28:1119-1122

Popescu SM, Melinte M, Suc J-P, Clauzon G, Quillevere F, Suto-Szentai M (2007) Earliest Zanclean age for the Colombacci and uppermost Di Tetto formations of the "latest Messinian" northern Apennines: new palaeoenvironmental data from the Maccarone section (Marche Province, Italy). Geobios 40:359-373 
Reichenbacher B, Kowalke T (2009) Neogene and present-day zoogeography of killifishes (Aphanius and Aphanolebias) in the Mediterranean and Paratethys areas. Palaeogeogr Palaeoclimatol Palaeoecol 281:43-56

Roveri M, Manzi V (2006) The Messinian Salinity Crisis: looking for a new paradigm? Palaeogeogr Palaeoclimatol Palaeoecol 238:386-398

Roveri M, Bassetti MA, Ricci-Lucchi F (2001) The Mediterranean Messinian Salinity Crisis: an Apennine foredeep perspective. Sediment Geol 140:201-214

Roveri M, Gallo AB, Rossi M, Gennari R, Iaccarino SM, Lugli S, Manzi V, Negri A, Rizzini F, Taviani M (2005) The Adriatic foreland record of Messinian events (Central Adriatic Sea, Italy). GeoActa 4:139-158

Shanmugan G (2011) Process-sedimentological challenges in distinguishing paleo-tsunami deposits. Nat Hazards 56:1-26

Shiki T, Cita MB (2008) Tsunami-affected sedimentary properties of the Mediterranean homogenites as an example of deep-sea tsunamiite. In: Shiki T, Minoura K, Tsuji Y, Yamazaki T (eds) Tsunamiites. Elsevier, Amsterdam, pp 203-216

Shiki T, Yamazaki T (2008) The term "tsunamiite". In: Shiki T, Minoura K, Tsuji Y, Yamazaki T (eds) Tsunamiites. Elsevier, Amsterdam, pp 5-7

Shiki T, Tachibana T, Fujiwara O, Goto K, Nanayama F, Yamazaki T (2008) Characteristic features of tsunamites. In: Shiki T, Minoura K, Tsuji Y, Yamazaki T (eds) Tsunamiites. Elsevier, Amsterdam, pp $1-405$

Smit J (1999) The global stratigraphy of the Cretaceous-Tertiary boundary impact ejecta. Ann Rev Earth Planet Sci 27:75-113

Smit J, Roep TB, Alvarez W, Montanari A, Claeys P, Grajales-Nishimura JM, Bermudez J (1996) Coarse grained, clastic sandstone complex at the K/T boundary around the Gulf of Mexico: deposition by tsunami waves induced by the Chicxulub impact? In: Ryder G, Fastovski D, Gartner S (eds) The Cretaceous-Tertiary event and other catastrophes in earth history, vol Sp. Pap. 307. Special Paper. Geol. Soc. of Amer., Boulder, pp 151-182

Sturkell E, Ormo J, Kolvak J, Wallin A (2000) Distant ejecta from the Lockne marine-target impact crater, Sweden. Meteorit Planet Sci 35(5):929-936

Sugawara D, Minoura K, Imamura F (2008) Tsunamis and tsunami sedimentology. In: Shiki T, Minoura K, Tsuji Y, Yamazaki T (eds) Tsunamiites. Elsevier, Amsterdam, pp 9-50

Van den Berg GD, Boer W, de Haas H, van Weering TCE, van Wijk R (2003) Shallow marine tsunami deposits in Teluk Banten (NW Java, Indonesia), generated by the 1883 Krakatau eruption. Mar Geol 197:13-34

Yancey TE (1996) Stratigraphy and depositional environments of the Cretaceous-Tertiary boundary complex and basal Paleocene section, Brazos River, Texas. In: Jones JO, Freed RL (eds) Gulf Coast Association of Geological Societies, forty-sixth annual meeting, American Association of Petroleum Geologists regional meeting and Gulf Coast Section SEPM forty-fifth annual convention. Transactions-Gulf Coast Association of Geological Societies. Gulf Coast Association of Geological Societies, New Orleans 46, pp 433-442 